\title{
Ekonomska povijest u Časopisu za suvremenu povijest (1969. - 2018.)
}

\author{
JOSIP MIHALJEVIĆ \\ Hrvatski institut za povijest \\ Zagreb, Hrvatska \\ josip@isp.hr
}

\begin{abstract}
U radu se prikazuje kako je u historiografskom časopisu (Časopis za suvremenu povijest) tretirana gospodarska povijest. U članku se najprije upućuje na moguće definicije pojma gospodarske povijesti te daje kratak osvrt na razvoj te znanstvene subdiscipline u svjetskoj i hrvatskoj historiografiji. Najveći dio članka posvećen je pregledu sadržaja relevantnih radova na stranicama Časopisa, a nakon toga autor prikazuje i analizira brojčane pokazatelje o broju članaka, tematici koja se obrađivala, kategorijama i autorima radova i priloga objavljivanih u Časopisu od njegova osnutka 1969. do kraja 2018. godine. Uz nekoliko tabličnih i grafičkih prikaza autor je kao poseban prilog načinio kompletnu bibliografiju članaka koji se odnose na teme iz gospodarske povijesti.
\end{abstract}

Ključne riječi: Časopis za suvremenu povijest; ekonomska povijest; historiografija

\section{Uvod: o ciljevima i metodologiji rada te pojmu ekonomske povijesti}

Jedan od pokazatelja ,jačine" ekonomske povijesti ${ }^{1} u$ hrvatskoj historiografiji je i zastupljenost te tematike u znanstvenoj periodici, koja je jedan od temelja sustava znanosti u Hrvatskoj. Hrvoje Petrić, koji je analizirao stanje s člancima iz gospodarske povijesti objavljenima u znanstvenim časopisima u Hrvatskoj od 2000. do 2009., zaključio je da je polovica članaka (od ukupno 191) iz gospodarske povijesti objavljena u šest časopisa (Acta historicooeconomica, Radovi Zavoda za povijesne znanosti HAZU u Zadru, Ekonomska i ekohistorija, Scrinia Slavonica, Povijesni prilozi i Časopis za suvremenu povijest). ${ }^{2}$ Cilj je ovoga rada detaljnije analizirati kakvo je stanje $s$ jednim od tih časopisa - Časopisom za suvremenu povijest (ČSP) - odnosno u kojoj je mjeri

1 U ovome radu pojmove „gospodarstvo” i „ekonomija” koristim kao sinonime, isto kao i pojmove „povijest” i „historija” kada tvore sintagmu „ekonomska povijest” odnosno „ekonomska historija”.

2 PETRIĆ, „Prilozi poznavanju historiografije o gospodarskoj povijesti”, 120. 
gospodarska problematika (ekonomska historija) bila zastupana u ovome časopisu koji upravo slavi svojih prvih 50 godina kontinuiranoga objavljivanja.

Ekonomske teme u ČSP-u kao predmet istraživanja dotaknute su u jednom bibliografskom popisu iz 2007. godine - „Bibliografija radova iz gospodarske povijesti i ekohistorije objavljenih u Časopisu za suvremenu povijest i Crisu - časopisu Povijesnog društva Križevci". ${ }^{3}$ Unatoč korisnom popisu, ta kombinirana bibliografija ekonomske i ekološke povijesti nije dovoljno pregledna ako se promatra isključivo ekonomska povijest. K tome nije donesen nikakav popratni tekst ni osvrt na ekonomsku povijest, tako da smatram da se pitanje o udjelu i stanju ekonomske povijesti u ČSP-u može detaljnije analizirati.

Kvantitativnim metodama nastojat ću odgovoriti na pitanje koliko su ekonomske teme bile zastupljene i koji su autori bili najaktivniji. U analizi sadržaja (tekstova) ponudit ću pregled najvažnijih tema i strujanja u tadašnjoj i sadašnjoj hrvatskoj historiografiji te se pobliže osvrnuti na neke važnije radove i autore. Pokušat ću saznati i kako su ti autori u svojim radovima pristupali ekonomskim temama i nastojati detektirati odražava li ČSP stanje hrvatske ekonomske historije. Uz sadržajnu analizu napravit ću bibliografiju radova o zadanoj tematici te tablično i grafički prikazati zastupljenost radova iz sfere gospodarske povijesti i njihovih autora.

Prije same analize treba definirati pojam ekonomska povijest. ${ }^{4}$ Iako se u praktičnom smislu prakticira već dugo, teorijska definicija ekonomske povijesti i dalje je difuzna i teško da će ikad postojati neka koju će istodobno prihvaćati i povjesničari i ekonomisti. U vrijeme socijalizma u Jugoslaviji Rudolf Bićanić smatrao je da „ekonomska povijest treba da proučava sve odnose između ljudi, koji nastaju u vezi s njihovom aktivnosti u procesu materijalne reprodukcije". ${ }^{5}$ Adolf Dragičević u svojem je Leksikonu političke ekonomije ekonomsku povijest definirao kao „znanost koja proučava razvoj proizvodnih snaga i proizvodnih odnosa kroz historiju, u pojedinim društvima”. ${ }^{6}$ Recentniji Ekonomski leksikon Leksikografskoga zavoda „Miroslav Krleža” navodi da je ekonomska povijest

„Znanstvena disciplina koja proučava razvoj nacionalne i svjetske ekonomije s obzirom na djelovanje proizvodnih snaga, karakterističnih oblika organizacije proizvodnje, prometa i komuniciranja među ljudima te tipičnih institucija i oblika privređivanja. Znanstveno spoznate i definirane ekon. pojave, kategorije, pokazatelje, zakone i institucije e. p. proučava, kronološki prati i pokazuje u

3 PEKLIĆ, „Bibliografija radova iz gospodarske povijesti i ekohistorije”.

4 Ekonomsku povijest ne smijemo poistovjećivati s poviješću ekonomske misli, koja pripada primarno u sferu intelektualne historije.

5 BIĆANIĆ, „Ekonomska povijest medju ekonomskim i historijskim naukama”, 821.

6 DRAGIČEVIĆ, Leksikon političke ekonomije, 111. U nastavku natuknice još stoji: „Već spoznate ekonomske kategorije i zakone razvitka proizvodnih snaga i proizvodnih odnosa ekonomska povijest prati i više-manje kronološki prikazuje u svim njihovim specifičnim oblicima očitovanja, otkrivajući pri tom stvarne uzroke i učinke ekonomskih zbivanja u prošlosti. Ekonomska povijest ujedno prikuplja konkretne podatke iz ekonomske prošlosti ljudskoga društva, kojima se koriste sve ostale ekonomske nauke." Isto. 
konkretnim oblicima, otkrivajući pritom stvarne uzroke i učinke ekon. procesa i zbivanja u prošlosti. Prikuplja i podatke iz ekon. prošlosti kojima se koriste druge ekonomske znanosti"?

Vladimir Stipetić, autor sinteze o povijesti hrvatskoga gospodarstva, smatrao je da je ekonomska povijest „u biti kvantitativna analiza činjenica, koja se u velikoj mjeri koristi statističkim podacima”. ${ }^{8}$ U relevantnijim ekonomskim rječnicima na engleskome jeziku ekonomska povijest definira se kao subdisciplina unutar ekonomije i, u manjoj mjeri, historije, čiji je glavni fokus istraživanje ekonomskoga rasta i razvoja kroz vrijeme. ${ }^{9}$ Najpoznatija hrvatska teoretičarka povijesti, Mirjana Gross, ekonomsku je historiju smatrala integralnim dijelom i historije i ekonomije, s time da je prednost ipak davala povijesti, ujedno zagovarajući „otvaranje” znanosti jedne prema drugoj:

„U praksi ekonomska se historija razlikuje od ekonomije metodama i stupnjem generalizacije. Upravo ti različiti pristupi materiji istraživanja mogu postati osnova za plodnu suradnju historičara i ekonomista. Dakako, ekonomska historija ovisi o definiciji pojma 'politička ekonomija' (koja je ne smije 'progutati') i o njenu odnosu prema drugim granama historije. Kao znanost koja treba da proučava ekonomske strukture i procese ekonomska historija se ne može baviti isključivo određenim ekonomskim kategorijama, nego ekonomskim aspektom cjelovitog društvenog razvoja. Ako se privreda promatra kao povijesna pojava unutar cjeline društvenih odnosa, onda ekonomska historija mora postati integralni dio historije društvenih procesa. Suvremena ekonomska historija nastoji baviti se makroekonomskim pojavama a ne više samo ekonomskim institucijama. Njena je tendencija da istražuje mehanizam ekonomskih sustava, fenomene koji se ponavljaju i značaj njihove međusobne ovisnosti. Zato ona teži tipologiji i generalizaciji i služi se modelima ali njihova konstrukcija nije joj osnovni cilj, kao što je to slučaj u ekonomista. Posebnu pažnju ekonomska historija obraća pojavama dugog trajanja. Kao sve druge grane historije i ekonomska historija se koristi rezultatima ostalih društvenih znanosti." ${ }^{10}$

Ponekad je teško jasno razlučiti spada li neki znanstveni rad u domenu ekonomije ili sociologije, a ta ambivalencija jedno je od obilježja društvenih znanosti. Na taj je problem Mirjana Gross upozoravala još sedamdesetih godina XX. stoljeća govoreći da se pitanja kojima se bave društvene znanosti međusobno isprepleću, iako su institucionalno odijeljene i imaju na sveučilištima svoje posebne katedre. Dodatni je problem taj što se u pojedinim zemljama one različito nazivaju, „što nemaju iste subdiscipline, što se neprekidno uvijek nova i nova područja istraživanja proglašavaju samostalnim disciplinama”. ${ }^{11}$

\footnotetext{
7 SUNAJKO, Ekonomski leksikon, 178.

8 STIPETIĆ, Dva stoljeća razvoja hrvatskoga gospodarstva, 18.

9 FIELD, „Economic history”, 694.

10 GROSS, „Historija i društvene znanosti”, 80-81.

11 Isto, 73.
} 
Ekonomija, odnosno ekonomska znanost, kao društvena znanost, bliska je suvremenoj povijesnoj znanosti jer proučava „odnose među ljudima u procesu proizvodnje, raspodjele, razmjene i potrošnje materijalnih dobara” ${ }^{12}$ Prema brojnim autorima, ekonomska povijest čak je „najvažnije područje ekonomske analize". ${ }^{13}$ No, što sve spada u područje ekonomske povijesti? Prema bibliografiji o ekonomskoj historiji Jugoslavije iz 1978., u nju su uvršteni radovi redom iz sljedećih 14 kategorija: 1. rudarstvo, 2. šumarstvo, 3. stočarstvo, 4. naselja, selo-grad, stanovništvo i migracije, 5. ribarstvo, 6. sol i solane, 7. pomorstvo, 8. zadrugarstvo, 9. promet, 10. trgovina, 11. novac, banke, krediti, carine, cijene i mjere, 12. domaća radinost, cehovi, obrt, manufakture i industrija, 13. poljoprivreda, 14. opća djela i specijalni prilozi o različitim historijsko-ekonomskim i društvenim pitanjima. ${ }^{14}$ Ekonomska povijest svakako uključuje financijsku i poslovnu povijest te se u mnogočemu preklapa is područjima društvene povijesti poput demografske, ali i povijesti rada i radništva. Kada to imamo na umu, odmah dolazimo do jednoga metodološkog problema ovoga rada, a to je selekcija. Koje radove svrstati pod pojam ekonomske povijesti, a koje ne? Brojni radovi objavljeni u ČSP-u su „na granici” ili je ta "granica” često fluidna i difuzna, pa je ponekad teško odlučiti treba li neki rad svrstati u kategoriju ekonomske historije ili socijalne historije. To je pogotovo problematično kad promatramo razdoblje socijalizma, u kojem je proučavanje radničkoga pokreta i radništva bilo jednim od temeljnih istraživačkih programa (ciljeva). Prilikom selekcije odlučio sam se za „uži” pojam ekonomske povijesti, pod kojim podrazumijevam samo radove čija tematika barem jednim dijelom ulazi izravno u domenu ekonomske povijesti, pri čemu nisam uključivao radove iz povijesti rada i radništva osim ako nisu barem djelomično uključivali neke elemente ekonomske povijesti u užem smislu. ${ }^{15}$

U nekakvu idealtipskom stanju, metode ekonomske povijesti trebale bi biti svojevrsna kombinacija povijesnih i kvantitativnih (statističkih) metoda te primjene ekonomskih teorija na povijesne fenomene. Kako se u praksi malošto ostvaruje na način prikazan u teoriji, ili prema idealnom tipu, za potrebe ovoga rada pojam gospodarska/ekonomska povijest koristit ću u simplificiranom obliku u smislu istraživanja ekonomija, ekonomskih procesa i ekonomskih fenomena iz prošlosti.

\footnotetext{
12 DRAGIČEVIĆ, Leksikon političke ekonomije, 106, 119.

13 STIPETIĆ, Dva stoljeća razvoja hrvatskoga gospodarstva, 2.

14 ERCEG, Bibliographia historico-oeconomica Iugoslaviae.

15 Kriteriji selekcije uzrokom su različitoga broja članaka objavljenih u ČSP-u od 2000. do 2009. koji donosim u ovome radu i broja koji donosi Hrvoje Petrić u svojem pregledu. Po mojem kriteriju u tom razdoblju objavljeno je 10 znanstvenih članaka (vidi tablicu 2), a Petrić navodi brojku od 14 radova. Vidi: PETRIĆ, „Prilozi poznavanju historiografije o gospodarskoj povijesti”, 123.
} 


\section{Ekonomska povijest i historiografija}

Iako su povjesničari još od antičkih vremena pisali o nekim ekonomskim aspektima prošlosti, tek krajem XVIII. stoljeća, kad se svjetska ekonomija počinje drastičnije mijenjati u procesu industrijske revolucije, javlja se veće zanimanje za ekonomije prošlosti. Prema nekim autorima, jedno od prvih djela koja bismo mogli okarakterizirati kao pravu ekonomsku povijest jest knjiga History of the Cotton Manufacture Edwarda Bainesa iz 1835., ali ekonomska se povijest kao disciplina profilirala tek u posljednjoj četvrtini XIX. stoljeća. ${ }^{16}$ Krajem XIX. i početkom XX. stoljeća ona se najsnažnije razvijala unutar njemačke historijske škole, u kojoj su Gustav von Schmoller i Max Weber ostavili najveći pečat na njezin razvoj. ${ }^{17}$

$\mathrm{U}$ fokus povjesničara ekonomska povijest ponovno dolazi u vrijeme Velike gospodarske krize krajem dvadesetih godina XX. stoljeća. Marc Bloch i Lucien Febvre pokrenuli su 1929. novi časopis, koji su nazvali Annales d'historie économique et sociale, želeći „sasvim zapostavljenoj ekonomskoj historiji osigurati središnje mjesto u historijskom istraživanju” ${ }^{18}$ Druga generacija te slavne škole Anala nakon Drugoga svjetskog rata još će jače promovirati ekonomsku historiju. Vjerojatno najpoznatiji povjesničar u povijesti historiografije, Fernand Braudel, usmjerio je mlade istraživače na istraživanje „prije svega ekonomskih i društvenih struktura s upotrebom kvantitativnih metoda". ${ }^{19}$ Uz njega je novi trend najviše promovirao Ernest Labrousse, koji je gotovo tri desetljeća djelovao kao profesor ekonomske historije na pariškoj Sorboni i „koji uvodi na scenu komparativnu kvantitativnu analizu gospodarskog razvoja”. ${ }^{20}$ Prema M. Gross, velika je Labrousseova zasluga to da su ekonomska i socijalna historija postale dominantne među pripadnicima struje oko Anala. ${ }^{21}$ Pod njihovim utjecajem pedesetih i šezdesetih godina XX. stoljeća ekonomska povijest doživjet će svoj vrhunac kao historijska subdisciplina, pa je na važnost ekonomske povijesti upozoreno i na Kongresu ekonomskih povjesničara u Stockholmu 1960. godine. ${ }^{22}$

I u liberalno-demokratskome i u socijalističkome svijetu vođene su opširne diskusije o ulozi i mjestu ekonomske historije. Jednu takvu diskusiju proveo je i časopis Jahrbuch für Wirtschaftsgeschichte, ${ }^{23}$ pokrenut 1960. u Njemačkoj Demokratskoj Republici. Polemikā o ekonomskoj historiji bilo je i u socijalističkoj Jugoslaviji još i ranije. Rudolf Bićanić tvrdio je 1952. da ekonomska povijest „nije historijska nauka u užem smislu”, nego da je ona „ekonomska

16 BOLDIZZONI, The Poverty of Clio: Resurrecting Economic History, 2-3.

17 FIELD, „Economic history”, 694-695.

18 GROSS, Suvremena historiografija, 212.

19 Isto, 240.

20 STIPETIĆ, Dva stoljeća razvoja hrvatskoga gospodarstva, 9.

21 GROSS, Suvremena historiografija, 241.

22 KOLAR-DIMITRIJEVIĆ, „Proučavanje ekonomsko-socijalne strukture”, 158.

23 Isto. 
nauka, koja ispituje unutrašnje uzročne veze, tj. djelovanje ekonomskih zakona”, te „da ekonomski historičar mora biti ekonomist”. ${ }^{44}$ Njemu se usprotivio Fran Zwitter, koji je ekonomsku povijest smatrao samo dijelom povijesne znanosti. ${ }^{25}$ Njihova polemika u Zgodovinskom časopisu nastavljena je i $1955 .{ }^{26}$ a diskusije o ulozi ekonomske historije u Hrvatskoj vođene su i u prosincu 1957. na Međufakultetskoj konferenciji u Zagrebu. ${ }^{27}$

Najpotpuniji pregled razvoja hrvatske historiografije o gospodarskoj povijesti dao je Hrvoje Petrić. ${ }^{28}$ On početak proučavanja gospodarskih pojava u Hrvatskoj vidi u istraživanjima srednjovjekovlja. Preuzimajući stav Tomislava Raukara, ustvrdio je da su istraživanja znanstvenika iz XIX. stoljeća Petra Matkovića, Ivana Tkalčića i Radoslava Lopašića bila „zameci hrvatske ekonomske historiografije". ${ }^{29}$ Njima se nakon Prvoga svjetskog rata pridružuje Grga Novak, koji 1923. objavljuje prvu monografiju iz gospodarske povijesti u hrvatskoj historiografiji - Split u svjetskom prometu. ${ }^{30}$ No, Raukar ocjenjuje da ekonomska povijest tada još uvijek nije bila zasebna znanstvena disciplina u hrvatskoj srednjovjekovnoj historiografiji te da je to postala tek sredinom XX. stoljeća. ${ }^{31}$ Jedan od prvih povjesničara koji su u većoj mjeri utjecali na razvoj ekonomske povijesti u Hrvatskoj bio je Josip Matasović, koji je svojim radom između dva svjetska rata, prvenstveno objavljujući članke i uređujući časopis Narodna starina, davao poticaj za istraživanje gospodarske povijesti i znatno utjecao na kasnije poznate ekonomske povjesničare Miroslavu Despot i Igora Karamana. ${ }^{32} \mathrm{U}$ kontekstu razvoja interesa za gospodarsku povijest između dva rata nije nevažno ni ime Rudolfa Horvata, koji je napisao nekoliko znanstvenih i više desetaka popularnih tekstova u kojima se obrađivala ekonomska povijest. $^{33}$

Sve jači interes za gospodarske teme nakon Drugoga svjetskog rata doveo je do institucionalizacije gospodarske povijesti. Pritom je nekoliko znanstvenika ostavilo najdublji pečat. Prvu organiziranu nastavu iz gospodarske povijesti imao je Pravni fakultet u Zagrebu. Predmet pod nazivom „Ekonomska povi-

\footnotetext{
${ }^{24}$ BIĆANIĆ, „Ekonomska povijest medju ekonomskim i historijskim naukama”, 824.

25 ZWITTER, „Odgovor”.

26 BIĆANIĆ, „Još jedna riječ o ekonomskoj povijesti”.

27 KOLAR-DIMITRIJEVIĆ, „Proučavanje ekonomsko-socijalne strukture”, 159.

28 PETRIĆ, „Prilozi poznavanju historiografije o gospodarskoj povijesti”. Pregled gospodarske povijesti jedne regije dala je ŽIVAKOVIĆ-KERŽE u članku „Zastupljenost tema gospodarske povijesti Slavonije, Srijema i Baranje u hrvatskoj historiografiji”.

${ }_{29}$ RAUKAR, Srednjovjekovne ekonomije i hrvatska društva, 5. Vidi i: PETRIĆ, „Prilozi poznavanju historiografije o gospodarskoj povijesti”, 98.

30 Godina izdavanja knjige možda je i 1921. jer u primjerku koji se čuva u Nacionalnoj i sveučilišnoj knjižnici u Zagrebu postoji dvostruka naslovnica. Na vanjskoj stoji godina 1923., s Nakladom knjižare Vinko Jurić kao izdavačem, a na unutrašnjoj stranici navedena je godina 1921., a Hrvatska štamparija kao izdavač. Vidi: NOVAK, Split u svjetskom prometu.

31 RAUKAR, Srednjovjekovne ekonomije i hrvatska društva, 5.

32 PETRIĆ, „Prilozi poznavanju historiografije o gospodarskoj povijesti”, 98-99.

33 PAVIĆ, „Ekonomska povijest”, 11.
} 
jest Hrvatske" od 1946. do 1950. izvodio je Rudolf Bićanić. ${ }^{44} \mathrm{Na}$ Međufakultetskoj konferenciji filozofskih fakulteta Jugoslavije u Zagrebu 1949. prihvaćeno je načelo „da se politička ekonomija predaje u okviru historijskog studija, a ekonomskoj historiji da se posveti određena pažnja unutar pojedinih historijskih disciplina". ${ }^{35}$ Važan događaj u institucionalizaciji bilo je i otvaranje katedre za ekonomsku historiju na Ekonomskom fakultetu Sveučilišta u Zagrebu, na kojoj je prvi predavač bio Mijo Mirković, ${ }^{36}$ koji je od 1953. predavao predmet „Ekonomska historija FNRJ”. ${ }^{37}$ „U program rada te katedre ušlo je proučavanje bitnih materijalnih uvjeta života naroda u prošlosti i sadašnjosti i proučavanje ekonomskih i društvenih snaga koje su djelovale na te uvjete, a u toj formulaciji našlo je svoje mjesto i proučavanje struktura i položaja radničke klase."38 Mirković je pri Jugoslavenskoj akademiji znanosti i umjetnosti kao urednik 1951. započeo s objavljivanjem serije knjiga Građa za gospodarsku povijest Hrvatske $\mathrm{i}$ to je radio sve do 1962. godine. ${ }^{39}$

Do šezdesetih godina XX. stoljeća historiografija je više bila usmjerena na politička zbivanja, a manje na ekonomsku povijest, no to će se polako mijenjati upravo tijekom toga desetljeća, ${ }^{40}$ kada su sve učestalije primjene kvantitativnih metoda u gospodarskoj povijesti, ${ }^{41}$ a taj je proces pratila i daljnja institucionalizacija, ponajprije povijesti radništva, ali i drugih ekonomsko-historijskih tema. Za institucionalizaciju je jako važna i 1959. godina jer je tada Igor Karaman izabran za prvoga nastavnika ekonomske historije na povijesnoj grupi Filozofskoga fakulteta u Zagrebu. ${ }^{42}$ Filozofski fakultet tada će postati ,jedno od glavnih središta za istraživanje gospodarske povijesti, a posebno za odgoj budućih istraživača”."43

Kada je 1961. osnovan Institut za historiju radničkog pokreta u Zagrebu, prema programu je bilo predviđeno i istraživanje tema iz sfere gospodarske povijesti. Mira Kolar-Dimitrijević prisjećala se da je u to vrijeme u Institut "dolazio dr. Rudolf Bićanić i dr. Ivo Vinski te su oba bili savjetodavci za obradu gospodarskih pitanja, a oni su i autori koji su popunili svojim radovima 'Priloge za ekonomsku povijest Hrvatske' koji je izašao u Institutu 1967., a koji je svojim temama razbio krutost i vremensku ograničenost pisanja socijalističke političke ekonomije". ${ }^{44}$ Ekonomska se povijest u tom institutu počela inten-

\footnotetext{
34 PETRIĆ, „Prilozi poznavanju historiografije o gospodarskoj povijesti”, 101.

35 KOLAR-DIMITRIJEVIĆ, „Proučavanje ekonomsko-socijalne strukture”, 143.

36 U javnosti je više upamćen ostao po svojem književnom pseudonimu Mate Balota.

37 PETRIĆ, „Prilozi poznavanju historiografije o gospodarskoj povijesti”, 103.

38 KOLAR-DIMITRIJEVIĆ, „Proučavanje ekonomsko-socijalne strukture”, 159.

39 PETRIĆ, „Prilozi poznavanju historiografije o gospodarskoj povijesti”, 104. Sedamdesetih i osamdesetih urednički posao te serije vodit će Vladimir Stipetić. Isto, 113.

40 ŽIVAKOVIĆ-KERŽE, „Doprinos Ive Mažurana istraživanju gospodarske povijesti”, 100.

41 PETRIĆ, „Prilozi poznavanju historiografije o gospodarskoj povijesti”, 106.

${ }^{42}$ Isto, 105. Mira Kolar-Dimitrijević donosi podatak da se radilo o 1960. godini. Vidi: KOLAR-DIMITRIJEVIĆ, „Proučavanje ekonomsko-socijalne strukture”, 159.

43 PETRIĆ, „Prilozi poznavanju historiografije o gospodarskoj povijesti”, 106.

44 KOLAR-DIMITRIJEVIĆ, „Projekt povijesti Zagrebačkog velesajma”, 322.
} 
zivnije obrađivati tek nakon što je u lipnju 1963. održan sastanak povjesničara, ekonomista i demografa na kojem je zaključeno „da se počne proučavati ekonomska povijest Hrvatske”. ${ }^{45}$ Ta je odluka donekle i zaživjela jer je Institut te godine zaposlio Miroslavu Despot, dotadašnju kustosicu Muzeja za umjetnost i obrt u Zagrebu. Mira Kolar-Dimitrijević smatra da je Miroslava Despot, uz Miju Mirkovića i Rudolfa Bićanića, činila „prvi trolist gospodarskih povjesničara nakon Drugog svjetskog rata". ${ }^{46}$ Despot je u Institutu radila sve do umirovljenja 1973., a pored toga je od 1957. do 1967. honorarno predavala gospodarsku i kulturnu povijest novoga vijeka na Odjelu za geografiju Prirodoslovno-matematičkoga fakulteta Sveučilišta u Zagrebu. ${ }^{47} \mathrm{U}$ istom institutu, najprije kao djelatnica u institutskom Arhivu (1965.), a potom kao mlada ekonomska povjesničarka u znanstvenom odjelu (1966.), svoj rad započela je i Mira Kolar-Dimitrijević. ${ }^{48}$ Kad se promatra ekonomska povijest u ČSP-u, ona će ostaviti najdublji trag, o čemu će više riječi biti u nastavku teksta.

Sedamdesete su bile desetljeće jačanja ekonomske povijesti. Godine 1972. osnovana je Komisija za ekonomsku historiju Saveza društava historičara Jugoslavije, u koju su iz Hrvatske pozvani Miroslava Despot, Ivan Erceg, Ivan Kampuš, Igor Karaman, Anđelko Runjić i Vladimir Stipetić. ${ }^{49}$ Krajem iste godine u Zagrebu je organiziran prvi okrugli stol ekonomskih povjesničara o industrijskoj revoluciji. ${ }^{50}$ Dvije godine poslije objavljen je prvi broj časopisa Acta historico-oeconomica Iugoslaviae. ${ }^{51}$ Redakcija toga časopisa zajedno s Komisijom za ekonomsku historiju Jugoslavije 1978. objavit će prvu veliku bibliografiju posvećenu ekonomskoj povijesti, čiji je glavni urednik bio Ivan Erceg. ${ }^{52}$ Od sredine sedamdesetih stvara se nova generacija gospodarskih povjesničara, koji su gospodarskoj povijesti pristupali na novi način, dijelom pod utjecajem škole Anala (npr. Tomislav Raukar, Miroslav Bertoša, Marijan Maticka). ${ }^{53}$ Tada se kao subdisciplina ekonomske povijesti počinje razvijati i povijest poduzetništva, koja će svoj vrhunac doživjeti tijekom osamdesetih. ${ }^{54}$

\footnotetext{
${ }^{45}$ KOLAR-DIMITRIJEVIĆ, „Proučavanje ekonomsko-socijalne strukture”, 159.

46 Mirković i Bićanić već su u međuratnom razdoblju bili etablirani znanstvenici koji su napisali brojne radove iz sfere ekonomske povijesti. Miroslava Despot spada u mlađu generaciju, a iako je povijest kojom se bavila nazivala „kulturnom poviješću” te je takav predmet i predavala na Prirodoslovno-matematičkom fakultetu, Mira Kolar-Dimitrijević smatra da ona ima zaslužno mjesto u povijesti hrvatske historiografije kao jedna od pionirki ekonomske historije. KOLAR-DIMITRIJEVIĆ, PETRIĆ, „Nekoliko uvodnih riječi”, 5. Opširnije vidi: KOLAR-DIMITRIJEVIĆ, „Miroslava Despot”.

47 PAVLIČEVIĆ, „Uz osamdesetu obljetnicu”; PETRIĆ, „Prilozi poznavanju historiografije o gospodarskoj povijesti”, 107.

48 KORUNIĆ, „Prof. dr. Mira Kolar”, 7.

49 PETRIĆ, „Prilozi poznavanju historiografije o gospodarskoj povijesti”, 109.

50 VUČO, „Industrijska revolucija u jugoslavenskim zemljama”, 9.

51 Godine 1991. časopis će iz svojega naziva izbaciti riječ Iugoslaviae.

52 ERCEG, Bibliographia historico-oeconomica Iugoslaviae.

53 PETRIĆ, „Prilozi poznavanju historiografije o gospodarskoj povijesti”, 109.

54 BRANĐOLICA, „Poduzetnička historija i hrvatska historiografija”, 62.
} 
Od kraja osamdesetih, a pogotovo od početka devedesetih, ekonomska historija u Hrvatskoj je, kako je to istaknuo Drago Roksandić, „nesumnjivo gubila 'dah"' ${ }^{55}$ To je razdoblje u kojem je i na državnoj razini napušten marksističko-materijalistički svjetonazor i istraživački okvir. Pritom je i ekonomska povijest mnogo izgubila, a povijest radništva, koja je dotad bila jednim od glavnih ciljeva historije u socijalizmu, počela je padati u drugi plan. I u sveučilišnoj nastavi gubi se interes za ekonomsku povijest. Do kraja desetljeća ona se na Filozofskom fakultetu u Zagrebu svela na kolegij „Gospodarska i socijalna povijest novog vijeka”, koji je posljednji put izvođen u akademskoj godini 1999./2000., što je, prema Petriću, „bitno utjecalo na daljnje rastakanje gospodarsko-povijesne infrastrukture", usprkos tome što je M. Kolar-Dimitrijević nastavila održavati po jedan izborni kolegij iz gospodarske povijesti godišnje. Od njezina umirovljenja 2003. pa do 2008. na Filozofskom fakultetu nije držana nastava iz gospodarske povijesti. ${ }^{56}$ I na ekonomskim fakultetima nastava iz ekonomske povijesti Jugoslavije bila je ukinuta odmah nakon raspada jugoslavenske države. ${ }^{57}$

Od početka ovoga stoljeća ekonomska historija ponovno će postati donekle aktualna u hrvatskoj historiografiji. Već na prijelazu tisućljeća na I. kongresu hrvatskih povjesničara, održanom krajem 1999. u Zagrebu, jedna od sekcija djelovala je pod nazivom "Gospodarska povijest”. ${ }^{8} \mathrm{Na}$ toj je sekciji raspravljano i predloženo osnivanje Društva za hrvatsku ekonomsku povijest i ekohistoriju, što je realizirano 2005., a to je društvo ujedno pokrenulo novi časopis pod nazivom Ekonomska i ekohistorija: časopis za gospodarsku povijest i povijest okoliša.$^{59}$ Uskoro su na Filozofski i Ekonomski fakultet u Zagrebu vraćeni nastavni sadržaji iz gospodarske povijesti, a prošireni su i na dio novoosnovanih studija povijesti. Petrić je u svojem pregledu istaknuo da, premda su se „umnožile institucionalne podloge”, „nema više jedinstvenih vizija daljnjeg razvoja gospodarske povijesti u Hrvatskoj usmjeravanih od pojedinih snažnih istraživačkih osobnosti” te da je gospodarska povijest „uglavnom svedena na vrlo tradicionalne obrasce”. ${ }^{60}$ Tvrdi ipak da ,ima dosta prostora za optimizam jer je iz brojnosti pojedinačnih istraživanja i inicijativa moguće utvrditi da postoji daljnja perspektiva gospodarske povijesti u Hrvatskoj”. ${ }^{61}$

\footnotetext{
55 ROKSANDIĆ, „Na kraju prvog broja”, 147.

56 PETRIĆ, „Prilozi poznavanju historiografije o gospodarskoj povijesti”, 120.

57 Isto, 121.

58 U toj sekciji izlagali su Fani Cega, Ivan Erceg, Dragutin Feletar, Sabina Florence Fabijanec, Mira Kolar-Dimitrijević, Mithad Kozličić, Hrvoje Petrić, Štefanija Popović, Boris Suljagić, Ivica Šute, Zlatko Vire, Milan Vrbanus, Vesna Vučevac-Bajt i Zlata Živaković-Kerže. KOLAR-DIMITRIJEVIĆ, „Gospodarska povijest”, 839. U trećem broju ČSP-a za 2001. objavljena su četiri rada s te sekcije, o kojima više u nastavku teksta.

59 PETRIĆ, „Prilozi poznavanju historiografije o gospodarskoj povijesti”, 122.

60 Isto, 122-123.

61 Isto, 123.
} 


\section{Statistički pokazatelji}

U ČSP-u su od 1969. do 2018. objavljena 1043 znanstvena rada. ${ }^{62}$ Od toga je gospodarskim temama bio posvećen samo $51 \mathrm{rad}$, što iznosi $4,88 \%$, a to je otprilike nešto manje nego što je bio slučaj s Historijskim zbornikom, koji ih je imao oko $6 \% .{ }^{63}$ Indikativno je da je i broj prikaza mnogo manji (32) od broja članaka, što znači da se ni literatura nije znatnije pratila, ili barem da pisanje prikaza nije bilo većim motivom.

U razdoblju sedamdesetih (uključujući i prvi broj iz 1969.) objavljeno je 8 članaka i 10 prikaza. U osamdesetima (1980. - 1989.) objavljeno je 13 članaka i samo 2 prikaza, a u devedesetima (1990. - 1999.) čak 14 članaka i 3 prikaza. Prvo desetljeće ovoga stoljeća (2000. - 2009.) donijelo je 10 članaka i 8 prikaza. Od 2010. do kraja 2018. objavljeno je 6 znanstvenih radova i 9 prikaza. Indikativno je da se osamdesetih i devedesetih pisalo vrlo malo prikaza. Novo je tisućljeće donijelo nešto češće praćenje ekonomsko-povijesne literature.

Ukupno je svoje znanstvene članke u ČSP-u objavilo 33 autora. Osim Mire Kolar-Dimitrijević, koja ih je objavila čak 17 (33,33\% od ukupnoga broja objavljenih članaka), s više od jednoga članka javili su se Zdenka ŠimončićBobetko (3) i Tomislav Anić (2). Sedamnaestero autora javilo se svojim prikazima. Pored članaka, Kolar-Dimitrijević napisala je i najveći broj prikaza - 5, koliko su napisali i Miroslava Despot i Milan Vrbanus. Zanimljivo je da je Kolar-Dimitrijević jedina u ČSP-u objavljivala i članke i prikaze vezane za temu gospodarske povijesti. Podatak da je samo jedan članak napisan u suautorstvu (Goran Arčabić i Iva Kraljević) govori da se na ekonomsko-historijskim temama rijetko radilo timski unatoč tomu što je upravo u toj znanstvenoj subdisciplini, zbog njezinih interdisciplinarnih obilježja, to više nego nužno.

${ }^{62}$ JELASKA MARIJAN, „Pedeset godina Časopisa za suvremenu povijest”, 88.

${ }_{63}$ U svojem pregledu razvoja hrvatske ekonomske historije Hrvoje Petrić ustvrdio je da deklarirano nastojanje na području jačanja gospodarske povijesti u hrvatskoj historiografiji u časopisu Historijski zbornik „nije naišlo na odgovarajući odjek jer je od 1948. do početka 1960-tih godina na njegovim stranicama objavljeno samo oko 6 posto znanstvenih i stručnih članaka vezanih uz gospodarsku povijest. Približni udio gospodarske povijesti na stranicama Historijskog zbornika je ostao i u periodu 1961. - 1975., da bi se blago povećao u razdoblju 1976. - 1990., te bitno smanjio nakon 1991. godine”. PETRIĆ, „Prilozi poznavanju historiografije o gospodarskoj povijesti”, 102-103. 
JOSIP MIHALJEVIĆ, Ekonomska povijest u Časopisu za suvremenu povijest (1969. - 2018.).. ČSP, br. 3, 741-784 (2019)

Tablica 1. Broj i vrsta objavljenih radova po godinama

\begin{tabular}{|c|c|c|}
\hline Godina & Članci & Prikazi \\
\hline 1969. & 1 & \\
\hline 1970. & & 1 \\
\hline 1971. & & \\
\hline 1972. & 1 & 1 \\
\hline 1973. & & 4 \\
\hline 1974. & 1 & \\
\hline 1975. & 3 & \\
\hline 1976. & 1 & 1 \\
\hline 1977. & 1 & \\
\hline 1978. & & 3 \\
\hline 1979. & & \\
\hline 1980. & 1 & 1 \\
\hline 1981. & & \\
\hline 1982. & 1 & \\
\hline 1983. & & \\
\hline 1984. & 3 & \\
\hline 1985. & 1 & \\
\hline 1986. & 1 & \\
\hline 1987. & 2 & 1 \\
\hline 1988. & 2 & \\
\hline 1989. & 2 & \\
\hline 1990. & 2 & \\
\hline 1991. & & \\
\hline 1992. & 3 & \\
\hline 1993. & 1 & \\
\hline
\end{tabular}

\begin{tabular}{|l|c|c|}
\hline Godina & Članci & Prikazi \\
\hline 1994. & 1 & \\
\hline 1995. & 1 & 1 \\
\hline 1996. & 1 & \\
\hline 1997. & & \\
\hline 1998. & 2 & 1 \\
\hline 1999. & 3 & 1 \\
\hline 2000. & & 1 \\
\hline 2001. & 4 & 1 \\
\hline 2002. & & 2 \\
\hline 2003. & & \\
\hline 2004. & 1 & 1 \\
\hline 2005. & 1 & 3 \\
\hline 2006. & & \\
\hline 2007. & 3 & \\
\hline 2008. & 1 & \\
\hline 2009. & & \\
\hline 2010. & & 2 \\
\hline 2011. & & \\
\hline 2012. & & \\
\hline 2013. & 1 & 3 \\
\hline 2014. & 3 & 2 \\
\hline 2015. & & 1 \\
\hline 2016. & & \\
\hline 2017. & & \\
\hline 2018. & 2 & 1 \\
\hline UKUPNO & 51 & 32 \\
\hline & & \\
\hline & & \\
\hline & & \\
\hline & & \\
\hline & & \\
\hline & & \\
\hline & & \\
\hline & & \\
\hline & & \\
\hline & & \\
\hline & & \\
\hline & & \\
\hline & & \\
\hline
\end{tabular}


Grafički prikaz 1. Broj objavljenih članaka i prikaza po godinama

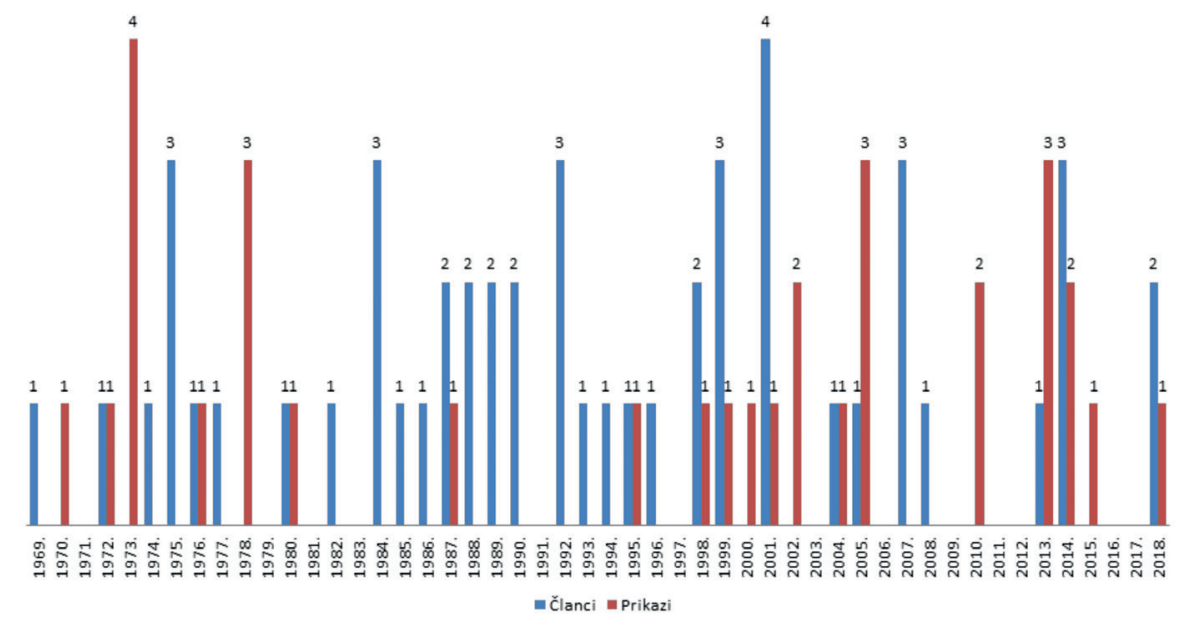

Tablica 2. Autori tekstova vezanih za gospodarsku povijest u $\check{C} S P$-u

\begin{tabular}{|l|c|c|}
\hline \multicolumn{1}{|c|}{ Autori } & Članci & Prikazi \\
\hline Kolar-Dimitrijević, Mira & 17 & 5 \\
\hline Šimončić (Bobetko), ${ }^{64}$ Zdenka & 3 & \\
\hline Anić, Tomislav & 2 & \\
\hline Arčabić, Goran i Kraljević, Iva & 1 & \\
\hline Artuković, Mato & 1 & \\
\hline Berend, Iván T. & 1 & \\
\hline Brkljača, Seka & 1 & \\
\hline Čepo, Zlatko & 1 & \\
\hline Dukovski, Darko & 1 & \\
\hline Dukovski, Vedran & 1 & \\
\hline Golec, Ivica & 1 & \\
\hline Gross, Mirjana & 1 & \\
\hline Jonjić, Tomislav & 1 & \\
\hline Jovanović, Vladan & 1 & \\
\hline Maslek, Jasenka & 1 & \\
\hline Maticka, Marijan & 1 & \\
\hline Mijatović, Nikola & 1 & \\
\hline
\end{tabular}

${ }^{64}$ Od 1984. potpisana s prezimenom Šimončić-Bobetko. 
JOSIP MIHALJEVIĆ, Ekonomska povijest u Časopisu za suvremenu povijest (1969. - 2018.).. ČSP, br. 3, 741-784 (2019)

\begin{tabular}{|c|c|c|}
\hline Autori & Članci & Prikazi \\
\hline Milak, Enes & 1 & \\
\hline Miljković, Marko & 1 & \\
\hline Mitterauer, Michael & 1 & \\
\hline Olujić, Boris & 1 & \\
\hline Petrić, Hrvoje & 1 & \\
\hline Ratkajec, Hrvoje & 1 & \\
\hline Ribić, Vilim & 1 & \\
\hline Stanić, Igor & 1 & \\
\hline Szabo, Agneza & 1 & \\
\hline Šute, Ivica & 1 & \\
\hline Turkalj, Jasna & 1 & \\
\hline Valentić, Mirko & 1 & \\
\hline Vinaver, Vuk & 1 & \\
\hline Virc, Zlatko & 1 & \\
\hline Živaković-Kerže, Zlata & 1 & \\
\hline Despot, Miroslava & & 5 \\
\hline Vrbanus, Milan & & 5 \\
\hline Barić, Nikica & & 2 \\
\hline Bencetić, Lidija & & 2 \\
\hline Janjatović, Bosiljka & & 2 \\
\hline Bijelić, Borislav & & 1 \\
\hline Crnjac, Maja & & 1 \\
\hline Gotovac, Antonio & & 1 \\
\hline Grgić, Stipica & & 1 \\
\hline Lakić, Zoran & & 1 \\
\hline Matanović, Damir & & 1 \\
\hline Matijević, Margareta & & 1 \\
\hline Matković, Hrvoje & & 1 \\
\hline Melčić, Dunja & & 1 \\
\hline Strčić, Petar & & 1 \\
\hline Vojak, Danijel & & 1 \\
\hline UKUPNO & 51 & 32 \\
\hline
\end{tabular}




\section{Pregled radova o ekonomskim temama u Časopisu za suvremenu povijest}

Ekonomske teme u ČSP-u otvorene su već u prvom broju, odnosno dvobroju (1-2) 1969., u rubrici „Izvještaji o znanstvenim rezultatima” tekstom Mire Kolar-Dimitrijević pod naslovom „Proučavanje ekonomsko-socijalne strukture i položaja radničke klase u Hrvatskoj između dva rata u našoj poslijeratnoj literaturi”. Taj poduži članak bio je početak njezinih ispitivanja strukture i položaja onoga što se tada nazivalo radničkom klasom u međuratnoj Hrvatskoj. U pet poglavlja rada obradila je isto toliko „društvenih znanosti”65 (historija, ekonomija, demografija, radno pravo i sociologija), odnosno prikazala stanje te znanosti u odnosu na istraživanje položaja radničke klase. Ona naglašava da su strukture i položaj radničke klase u Jugoslaviji proučavani „u okvirima historije radničkog i Sindikalnog pokreta, iako treba naglasiti da je najvažnije radove s toga područja dala ekonomska historija" (str. 143). Osvrćući se na tu disciplinu, ističe da je za vrijeme Kraljevine Jugoslavije ekonomska historija „životarila u okviru političke i pravne historije”. Nalazeći se između tih dviju znanosti, „ona im je pružala čisto faktografske podatke iz ekonomske politike i ekonomike - prilagođene vremenu i političkim prilikama - budući da su ispitivanje materijalnih uvjeta života radničke klase i naroda uopće, kao i razgolićavanje kapitalističkih odnosa u privredi nerado gledali i upravni aparat i krupni kapital” (str. 159). Autorica je smatrala da „suvremena ekonomska historija u Jugoslaviji ima punu samostalnost”, ali da „njen odnos prema drugim srodnim disciplinama nije još uvijek riješen" (str. 159). Zaključila je da su istraživanja ekonomske historije usmjerena na ekonomsku strukturu zemlje te da „ne obrađuje dovoljno radničku klasu kao posebnu kategoriju, niti analizira ulogu radničke klase u stvaranju viška vrijednosti” (str. 178). Iz postojećih sinteza za Jugoslaviju „ne vidi se dovoljno ekonomska ni socijalna struktura radničke klase Hrvatske ni životni standard radnika”, a usto „većina ekonomskih radova govori o suvremenim ekonomskim problemima, a osvrt na razdoblje između dva rata dan je u tim radovima samo kao uvod u glavna razmatranja" (str. 178).

Drugi tekst vezan za ekonomsku povijest objavljen je u drugom broju 1970., a također ga je napisala Mira Kolar-Dimitrijević: „Istraživanja Ive Vinskog s posebnim osvrtom na radove iz ekonomske povijesti međuratnog razdoblja”. Iako je tekst objavljen u rubrici „Ocjene i prikazi”, radi se o iscrpnom osvrtu koji uvelike premašuje standardnu formu prikaza, pa je potrebno reći nešto više o njemu. Kolar-Dimitrijević ističe da radovi Ive Vinskoga zauzimaju posebno mjesto među ekonomskim djelima „zbog nastojanja Vinskog da današnju ekonomsku moć naše zemlje gleda kroz prizmu njenoga historijskog razvoja" (str. 239). Izravan povod za prikaz Vinskoga bila je njegova najnovija knjiga Klasna podjela stanovništva i nacionalnog dohotka Jugoslavije u 1938. godini (Zagreb, 1970.). Autorica je smatrala da je, „budući da je prikazana

\footnotetext{
65 Valja primijetiti da tada nije rađena distinkcija između društvenih i humanističkih znano-
} sti, pa se povijest svrstavalo u društvene znanosti. 
Vinskijeva knjiga rezultat njegovih dugogodišnjih napora na istraživanju nacionalnog bogatstva i srodnih problema [...] koristan za našu naučnu javnost kratak prikaz čitavog opusa toga veoma plodnog autora koji se od 1953. godine javlja brojnim prilozima u ekonomskoj literaturi” (str. 242). Zaključila je prikaz konstatacijom da veći dio golemoga opusa radova Vinskoga „predstavlja trajnu vrijednost, nastalu dugogodišnjim mukotrpnim i pionirskim radom tog istraživača" (str. 247).

I treći rad djelo je Mire Kolar-Dimitrijević, a radi se o tekstu „Statistički pregled stranih radnika i članova njihovih porodica u Jugoslaviji 1933. godine” objavljenom u trećem broju 1972. u rubrici „Građa”. Autorica je sama tvrdila da su ondje objavljeni dokumenti prvorazredan izvor za istraživače povijesti radništva. Građu, inače pohranjenu u Arhivu Jugoslavije u Beogradu (fond Ministarstva trgovine i industrije), predstavila je pregledno, u 20 tablica. U istom broju objavljen je i prikaz knjige Igora Karamana Privreda i društvo Hrvatske u 19. stoljeću (Zagreb, 1972.) iz pera Miroslave Despot.

Godine 1973. nije objavljen nijedan znanstveni rad, ali su objavljena četiri prikaza. Miroslava Despot napisala je prikaze knjiga o poduzećima u Hrvatskoj predstavljajući knjige o Tvornici papira Rijeka i Tvornici duhana i ambalaže Rovinj, a pod naslovom „Dvije monografije o povijesti poduzeća u Hrvatskoj”, objavljenim u trećem broju za 1973., predstavila je monografije o povijesti Inine rafinerije u Rijeci i o Međimurskoj trikotaži. Mira Kolar-Dimitrijević objavila je prikaz knjige Ivana Kovačevića Ekonomski položaj radničke klase u Hrvatskoj i Slavoniji 1867-1914 (Beograd, 1972.).

Godine 1974. u prvom svesku, u rubrici „Izvještaji o znanstvenim rezultatima”, objavljen je članak Marijana Maticke „Proučavanje razvoja poljoprivrede i ekonomsko-socijalnog položaja seljaštva u Hrvatskoj 1918-1941. godine u našoj poslijeratnoj literaturi”. Maticka je dao pregled literature o naslovnoj tematici s područja više znanosti, a prije svega ekonomske povijesti.

U drugom broju za 1975. objavljena su tri članka: u rubrici „Problemi metodologije povijesti” članak Michaela Mitterauera „O položaju ekonomske i socijalne historije u Austriji” i članak Mirjane Gross „Historija i društvene znanosti”, a u rubrici „Izvještaji o znanstvenim rezultatima” Zdenka Šimončić dala je „Pregled literature i štampanih izvora o industrijskom razvoju Hrvatske u razdoblju između dva svjetska rata”. Uredništvo ČSP-a stavilo je uz Mitterauerov članak napomenu s objašnjenjem zašto su zamolili Mitterauera, predstojnika Instituta za socijalnu i ekonomsku historiju i šefa Katedre za socijalnu historiju Sveučilišta u Beču, da u časopisu objavi ovaj tekst. U napomeni su iznesena dva razloga:

„1. U teškoj bitki da većina naših historičara spozna životnu potrebu naše struke, da se postupno pokrene s temelja događajne historije prema strukturalnoj historiji (tj. od istraživanja pojedinih političkih i ekonomskih događaja do proučavanja društvenih struktura), kao poticaj može poslužiti i prodor jedne povijesno uvjetovane naročito konzervativne i tradicionalne historiografije, kao 
što je austrijska, na području tzv. 'ekonomske i socijalne' historije. O toj grani historije vladaju u metodološkom pogledu različita shvaćanja. S marksističkog gledišta ona se uopće ne bi mogla prihvatiti kao posebna disciplina. Činjenica je, međutim, da je etablirana 'ekonomska i socijalna' historija (ili 'socijalna i ekonomska' historija) postala u nekim zemljama 'Zapada' poluga za ubrzano kretanje prema istraživanju društvenih struktura, kao što je to slučaj i u Austriji. 2. Izvještaj prof. Mitterauera dragocjen nam je i zato što ta nova istraživanja obuhvaćaju područje Habsburške Monarhije. On stoga služi kao upozorenje historičarima da se u interesu svoga rada upoznaju s tim rezultatima" (str. 61).

Mitterauer je prikazao organizaciju i rasprostranjenost institucija (fakulteta i instituta) koje se u potpunosti ili djelomično bave istraživanjem ekonomske i socijalne historije u Austriji. Prikazao je dotadašnje i aktualne projekte i izdavačke pothvate i dao jednu prilično pozitivnu sliku stanja s ekonomskom i socijalnom historijom u Austriji.

Iako članak Mirjane Gross prije svega spada u domenu rasprave o teoriji i metodologiji historije, na stranicama 74-81 raspravlja i o odnosu ekonomije i povijesti, zbog čega je i taj članak uvršten u ovaj pregled. Gross razmatra pitanje odnosa ekonomske historije i ekonomskih znanosti, tj. „onoga njihova dijela koji se (ne svuda) naziva političkom ekonomijom” (str. 74). Tu je problematiku smatrala bitnom za povjesničare iz više razloga, a kao prvi navodi sljedeće:

„Sinteza ekonomske historije i ekonomske teorije imala je presudnu ulogu pri genezi marksizma. Valja reći da je od svih historijskih disciplina ekonomska historija postigla najznačajnije rezultate $\mathrm{u}$ istraživanju društvene strukture i u teoretskom uopćavanju. Zato napredak cijele historije, prema idealu 'totalne' historije odnosno historije društvenih procesa, vodi velikim dijelom preko traženja i dostignuća ekonomske historije" (str. 74).

Rad Zdenke Šimončić napisan je kao prvi u obrađivanju šire teme o industrijskom razvoju Hrvatske međuratnoga razdoblja i, prema riječima autorice, trebao je biti polazištem za daljnje istraživanje. Autorica je ustvrdila da je ekonomska historija u nas „vrlo mlada naučna disciplina, a osobito ona njezina grana koja se bavi izučavanjem industrijskog razvoja Hrvatske. Ona ima vrlo malo iskustva, pa se retrospektivno može utvrditi nedovoljna istraženost spomenutog područja i mali broj objavljenih radova" (str. 102). Autorica je na raniju historiografiju gledala kritički, s time da je njezina kritika formulirana u duhu marksističkoga, odnosno komunističkoga očišta:

„Pojedini stručnjaci, koji su se bavili ekonomskom problematikom u prijeratnoj Jugoslaviji, stavljali su svoje znanje u službu vladajućeg sistema ili pojedinih grupa kapitala. Treba svakako izdvojiti nekolicinu naprednih i progresivnih autora u čiju objektivnost nemamo razloga sumnjati” (str. 102).

Kaže da je „u posljednje [...] vrijeme donekle i kod nas oživio interes za ekonomsku historiju” i da će ovaj njezin rad zbog toga poslužiti kao osno- 
va za daljnja istraživanja iako „nema mnogo ekonomsko-historijskih radova”, a „loše je i u pogledu izdavanja izvora i ekonomsko-historijske građe” (str. 102-103). Članak je zaključila konstatacijom da industrijski razvitak Hrvatske u međuraću nije monografski obrađen te da bi zbog toga trebalo „najprije izraditi iscrpne monografije o ekonomskom razvoju nekih važnijih industrijskih poduzeća ili industrijskih grana, da bi se na osnovi toga moglo pristupiti pisanju sinteze razvoja cjelokupne industrije Hrvatske u međuratnom razdoblju” (str. 131).

U prvom broju 1976. Vuk Vinaver objavio je članak „Svetska ekonomska kriza i jugoslavensko-italijanska trgovina (1930-34)”, u kojem proučava jugoslavensku ekonomsko-političku prošlost, nastojeći sagledati „predistoriju onoga 'skretanja ka Nemačkoj' koje je postalo dominantna crta jugoslavenske politike 1935-41. godine” (str. 39). Ekonomska kriza, koja je smanjila europsku trgovinu, te autarkična politika fašističke Italije snažno su utjecale na jugoslavenski izvoz 1920-ih, čija je tadašnja četvrtina bila usmjerena prema Italiji. Kako Pariz i Prag tada nisu mogli pomoći, logično je bilo, smatra autor, da se Jugoslavija okrene Berlinu, na koji je jugoslavenski režim već dugo računao kao na potencijalnu potporu u sukobu s Italijom i njezinim saveznicima. Vinaver je tada ustvrdio da su ekonomske promjene u doba krize jako utjecale na reorijentaciju jugoslavenske vanjske politike, koju se obično, ali prema autoru pogrešno, identificiralo s dvjema osobama - kneza Pavla i predsjednika vlade Milana Stojadinovića.

Iste godine u dvobroju (br. 2-3) objavljen je i prikaz dvotomne knjige Bernarda Stullija Prijedlozi i projekti željezničkih pruga u Hrvatskoj 1825-1863. (Zagreb, 1975.) iz pera Miroslave Despot. Pozitivan osvrt završila je riječima da je „Naša deficitarna gospodarska historiografija dobila [...] Stullijevom studijom [...] vrijedan doprinos, koji sam po sebi zaslužuje još podrobniju i sveobuhvatniju analizu" (str. 120).

Poznati mađarski stručnjak za ekonomsku historiju XIX. i XX. stoljeća Iván T. Berend održao je u ožujku $1977 .{ }^{66}$ niz predavanja u Centru za postdiplomske studije u Dubrovniku na tečaju „Istočni Jadran između Sredozemlja i Podunavlja (19. i 20. st.)". Jedno od tih njegovih predavanja objavljeno je u drugom broju za 1977. pod naslovom „Uloga ratarske proizvodnje i poljoprivrede u istočnoj i jugoistočnoj Evropi u razdoblju između dva svjetska rata”. Rukopis je s njemačkoga preveo Drago Dujmić. Analizirajući situaciju u Bugarskoj, Čehoslovačkoj, Jugoslaviji, Mađarskoj, Poljskoj i Rumunjskoj, Berend je zaključio da je poljoprivreda, „koja je bila jedna od najvažnijih pokretačkih snaga istočnoevropskog privrednog dinamizma od godina 1860 - 1880, u razdoblju između dva svjetska rata [bila] ranjiva točka nacionalne privrede. Poljoprivreda je bila usko grlo privrednog razvitka, koje je sprečavalo tako hitno potreban privredni razvitak i opći društveno-privredni preobražaj” (str. 36).

${ }^{66}$ U napomeni na početku članka stoji godina 1967., što je očita pogreška. 
Godine 1978. nije bilo znanstvenih članaka o gospodarskim temama osim triju prikaza. U prvom broju Bosiljka Janjatović prikazala je knjigu Josipa Zgaljića Radničkim stazama Riječke rafinerije (Zagreb, 1977.) te knjigu Mire KolarDimitrijević i Zlatka Čepe INA-Rafinerija nafte Sisak 1927-1977 (Sisak, 1977.). U drugom broju Mira Kolar-Dimitrijević prikazala je knjigu Obrena Blagojevića Naše finansije u periodu narodnooslobodilačke borbe 1941-1945 (Beograd, 1976.).

Godine 1979. nije bilo ni članaka ni prikaza relevantnih za gospodarsku povijest. U 1980. u drugom broju, koji je bio posvećen recentno preminulom Josipu Brozu Titu, objavljen je članak Zlatka Čepe „Tito - obnovitelj radničkog upravljanja”. U članku u kojem govori o povijesti komunizma i radničkoga pokreta Čepo prikazuje kako je jugoslavenska država uvela samoupravni ekonomski, a poslije i društveni model upravljanja. Sumirajući prva tri desetljeća jugoslavenskoga samoupravljanja, Čepo naglašava da se radi o „značajnoj prekretnici” i „dugotrajnom procesu prelaznog karaktera ka besklasnom komunističkom društvu" te da je za njegovo uvođenje u Jugoslaviji najzaslužniji Josip Broz Tito (str. 114).

U trećem broju za 1980. Mira Kolar-Dimitrijević objavila je prikaz knjige Miroslave Despot Industrija i trgovina građanske Hrvatske 1873-1880. Prilog gospodarskoj povijesti Hrvatske u doba banovanja Ivana Mažuranića (Zagreb, 1979.). Autorica je istaknula da je malo istraživača „koji su u toku svoga istraživačkog vijeka pregledali tako mnogo izvora kao što je to učinila dr Miroslava Despot. Zahvaljujući njenim objavljenim radovima, danas mnogo više znamo o gospodarskomu i kulturnom razvitku Hrvatske u osamnaestom i devetnaestom stoljeću. Riješene su mnoge enigme, ali i postavljeni upitnici za buduće istraživače toga razdoblja, jer je pokazan jedini mogući put kojim treba ići da bi se došlo do sinteze ekonomske povijesti Hrvatske" (str. 166). Na kraju je naglasila da bi bez radova Miroslave Despot znanje o gospodarskoj prošlosti Hrvatske bilo mnogo oskudnije „jer bi nedostajali detalji o razvoju pojedinih tvornica i radionica i o radu pojedinih privrednih ustanova važnih za daljnji razvoj i privrednog i kulturnog života Hrvatske u devetnaestom stoljeću, a upravo takva vrsta istraživanja dobiva u novije vrijeme sve značajnije mjesto u našoj gospodarskoj historiografiji” (str. 169).

U rubrici „Istraživanje povijesti komunističkog pokreta 1918. - 1941.,, koja je bila dio prvoga broja 1982., posvećenog dvodesetljetnom djelovanju Instituta za historiju radničkog pokreta, Mira Kolar-Dimitrijević objavila je članak „O ekonomsko-socijalnim istraživanjima”. U kratkom osvrtu autorica je zabilježila nekoliko podataka važnih za povijest ekonomske historije u Hrvatskoj. Tako saznajemo da je osnivanje „posebne studijske grupe za ekonomsku povijest" bilo predviđeno već u prvom programu rada Instituta za historiju radničkog pokreta Hrvatske. Saznajemo i da je u znanstveno-stručni odbor Instituta ušla ing. Dragica Rogić s Ekonomskoga fakulteta u Zagrebu zato što se smatralo „da se historija radničkog pokreta i revolucije ne može proučavati odvojeno od općih društveno-političkih kretanja” (str. 80). U početku se samo 
jedan suradnik bavio tom problematikom, „ali su u program svih sekcija ušle teme koje su se odnosile na ekonomsku problematiku, pa su one često tako kompleksno i istraživane” (str. 80). Istaknula je da je „istraživanje masovnih pojava - kakva je ekonomska povijest, a i položaj radništva - dugoročni posao i da ga je teško obaviti postojećim institutskim snagama i na dosadanji način" jer su arhivski fondovi „preveliki da bi pojedinci u toku svoga radnog vijeka mogli argumentirano izraditi veći broj radova, pa će ubuduće trebati raditi ekipno i znatno sustavnije" (str. 82). Zagovarala je jaču međuinstitutsku i interdisciplinarnu suradnju, premda je i dotadašnje rezultate smatrala nemalima.

Godine 1984. objavljena su tri članka. U drugom broju Mira Kolar-Dimitrijević objavila je pregledni članak ${ }^{67}$ „Odnos KPJ prema jugoslavenskoj radničkoj emigraciji u međuratnom razdoblju”. Članak je više iz sfere političke i socijalne povijesti jer u prvom redu govori o povijesti Komunističke partije Jugoslavije, ali pritom ipak donosi podatke o ekonomskim kretanjima. U mnoštvu podataka indikativan je onaj da je jugoslavenska ekonomska emigracija imala veliku financijsku moć, koja je vidljiva iz iseljeničkih doznaka koje su upućivane u zemlju. Emigracija je 1927. činila 7 \% stanovništva Jugoslavije, ali je njezin dohodak iznosio $36 \%$ cijeloga jugoslavenskoga nacionalnog dohotka (str. 66). Treba naglasiti da je u radu osjetan utjecaj tada prevladavajućega diskursa koji je (pre)naglašavao utjecaj Komunističke partije Jugoslavije. ${ }^{68}$

Zdenka Šimončić-Bobetko u trećem je broju za 1984. objavila izvorni znanstveni članak pod naslovom „Ekonomske i posjedovne prilike čabarskog područja i provođenje agrarne reforme između dva rata (1918-1941)". Autorica je zaključila da su konstantna "neizvjesnost i odugovlačenje provođenja agrarne reforme" imali štetne posljedice za stanovništvo i privredni razvoj čabarskoga područja. Istaknula je da je problem agrarne reforme potpuno $\mathrm{i}$ pravilno riješen tek nakon Drugoga svjetskog rata, kad je provedena potpuna eksproprijacija veleposjedničkih imanja (str. 73).

U istom je svesku Enes Milak objavio izvorni znanstveni članak „Uspostavljanje trgovinskih odnosa između Jugoslavije i Italije 1945-1947. godine". Članak koji uvelike kombinira ekonomsku i političku povijest prikazao je početak razvoja trgovinskih odnosa Jugoslavije i Italije, zemlje s kojom je Jugoslavija već tijekom 1945. ostvarila trgovinsku razmjenu. Italija je 1945. bila odredištem 2,6 \% cjelokupnoga izvoza Jugoslavije, a udio talijanske robe u jugoslavenskom uvozu iznosio je 5,6 \% (str. 78). Veoma plodna trgovinska razmjena između Italije i Jugoslavije pravno je regulirana Sporazumom o trgovini i ekonomskoj suradnji, potpisanim krajem studenoga 1947. u Rimu (str. 85). Milak ističe da je u jugoslavenskoj javnosti taj događaj ostao nezapažen jer

\footnotetext{
${ }^{67}$ Kategorizacija članaka u ČSP-u uvedena je s prvim brojem 1983. godine.

68 „Vodstvo KPJ - nalazeći se gotovo 15 godina izvan zemlje - vrlo je dobro poznavalo sudbinu ekonomskih emigranata. Zato je djelovanje jugoslavenskih komunista među emigrantima i njihovo uzajamno pomaganje prirodno i razumljivo. Stavivši se na čelo težnji emigranata, istinitim i poštenim informiranjem o situaciji u zemlji i u svijetu jugoslavenski su komunisti stvorili među našim iseljenicima širem svijeta jako antifašističko raspoloženje" (str. 83).
} 
„u uslovima veoma zategnutih političkih odnosa, zbog graničnog problema, jugoslovenska strana nije smatrala pogodnim da se javno ističe značaj sporazuma" (str. 85). Jugoslavensko se gospodarstvo time, a poslije i drugim sporazumima, postupno oslobađalo vezanosti za Sovjetski Savez, što je posebno bilo važno nakon sukoba jugoslavenskih komunista s Informbiroom 1948., kako je istaknuo i sam autor (str. 86).

U drugom broju 1985. Agneza Szabo objavila je izvorni znanstveni članak „Problemi i metode istraživanja društvene strukture nosilaca središnjih (političkih, privrednih i kulturnih) institucija u Zagrebu 1860-1873". Članak je temeljen na doktorskoj disertaciji koju je autorica napisala pod mentorstvom Igora Karamana i obranila 1983. na Filozofskom fakultetu u Zagrebu (str. 1). Autorica je istraživala povijest modernizacije primjenjujući tada novu serijalnu historiju, donoseći pritom mnogo podataka vezanih za povijest ekonomskih institucija i organizacija. Članak - od čijih je 36 stranica gotovo dvije trećine bilo ispunjeno popisima i tablicama sa serijama podataka - bio je prvo istraživanje takve vrste u jugoslavenskoj historiografiji. Prema autorici, taj njezin rad imao je zadatak „da prikaže tehniku rada na serijama što sam je upotrebljavala u svojoj disertaciji, jer želim olakšati posao onim mladim historičarima koji se pripremaju pisati socijalnu historiju i znaju da su pri tom neophodne i kvantitativne metode. Nadam se da će oni naći strpljenja da prouče sustav mojih serija. Od onih koji se boje brojki i smatraju da treba i dalje ustrajati isključivo na opisu pojedinih događaja bez ulaženja u društvene strukture ne mogu očekivati interes za ovakvu 'serijalnu' historiju' (str. 13).

Izvorni znanstveni članak Mire Kolar-Dimitrijević „Češko-jugoslavenske veze na privredno-racionalizatorskom i socijalnom području od prvoga svjetskog rata do velike svjetske krize" objavljen je u drugom broju 1986. godine. Sažetu verziju toga članka autorica je izložila na 14. zasjedanju Čehoslovačkojugoslavenske historijske komisije 1980. u Stubičkim Toplicama (str. 22). Autorica zaključuje da su veze između Čehoslovačke i Hrvata na polju unapređenja privrede i izgradnje socijalne politike nakon Prvoga svjetskog rata bile snažne te da su nosioci tih veza bili pretežno Hrvati školovani u Pragu poput Milana Marjanovića i Božidara Adžije.

Godine 1987. objavljena su dva članka i jedan prikaz. U prvom broju Mirko Valentić objavio je na 57 stranica izvorni znanstveni članak „Društvena i gospodarska struktura Prve banske pukovnije 1848-1881. godine”. Valentić je na primjeru jedne pukovnije, tj. komandno-upravne i društvene zajednice, analizirao razinu njezine gospodarske i društvene strukture te modernizacijske šanse. $U$ radu, koji također spada više u domenu socijalne historije, mnogo je prostora dano analizi ekonomije i ekonomsko-društvenoga sustava Banske krajine. U istom broju Zoran Lakić objavio je prikaz knjige Branislava Marovića Društveno-ekonomski razvoj Crne Gore 1945-1953 (Titograd, 1987.).

U drugom broju te godine Mira Kolar-Dimitrijević objavila je izvorni znanstveni članak ,'Munja, tvornica akumulatora u Zagrebu od osnivanja do nacionalizacije (1920-1945)”. To je bio prvi u seriji njezinih članaka iz pod- 
ručja poduzetničke povijesti objavljen u ČSP-u. Na osnovi očuvanih arhivskih materijala o radu tvornice autorica je rekonstruirala njezin razvoj te upozorila na ključne trenutke, poteškoće i uspjehe u poslovanju te prve i najveće tvornice akumulatora na Balkanu. U razvoju „Munje” detektirala je tri faze. „U prvoj fazi od 1920. do 1925. uvoze se gotovi akumulatori, u drugoj od 1925. do 1935. uvoze se dijelovi što se sastavljaju u radionici koja još uvijek nema tvornički karakter, iako zapošljava veći broj radnika. U trećoj fazi, koja obuhvaća period od 1935. godine do završetka rata, 'Munja' proizvodi akumulatore u novopodignutoj tvornici u Vrbanićevoj ulici i najveće je jugoslavensko poduzeće te vrste” (str. 82). Zaključila je da je „Munja” „bila afilirano poduzeće velikih stranih firmi koje su kreditirale njezinu proizvodnju. Poslovne transakcije obavljale su se posredovanjem Jugoslavenskoga bankarskog društva d.d., a njezina glavnica ne odražava pravu snagu toga poduzeća. U toj sprezi sa stranim kapitalom u bilanci nisu iskazani veliki poslovni rezultati, već se nastoji iskazati vrlo mali dobitak, odnosno čak deficit kako bi se izbjeglo plaćanje poreza. U toku velike svjetske krize dolazi do opadanja i vjerovnika i dužnika (1933), pa su manje zalihe sirovina, ali je ta kriza brzo prebrođena zahvaljujući izgradnji nove tvornice i modernizaciji tehnologije, te sve većim narudžbama od vojnih ustanova nakon što je od Njemačke prestalo plaćanje u naturi na račun reparacija" (str. 99-100). Rad je obogaćen brojnim statističkim prilozima i tablicama.

Članke napisane sličnom metodologijom Mira Kolar-Dimitrijević objavila je 1988. godine. ${ }^{69} \mathrm{U}$ prvom svesku, koji je bio dvobroj (br. 1-2), objavila je izvorni znanstveni članak „Zagrebačka tvornica baterija i džepnih svjetiljaka do 1945. godine (Prilog povijesti elektroindustrije Jugoslavije)”. Počeci tvornice vežu se za djelovanje Ivana Paspe još od kraja XIX. stoljeća. Paspa je 17. listopada 1918., pred sam kraj Austro-Ugarske Monarhije, svoju elektrotehničku radnju pretvorio u tvornicu pod nazivom Prva hrvatska tvornica za elektro industriju. Godine 1920. svojim baterijama dao je naziv „Croatia”, a pod tim je nazivom tvrtka poslije i poslovala. Od 14. studenog 1946. tvornica je uklopljena u elektroindustriju Hrvatske (ELIH).

Kolar-Dimitrijević objavila je u trećem broju 1988. izvorni znanstveni članak „Krapinska tvornica pokućstva i parna pilana d.d. od 1920. do 1925. godine". Radilo se o jednom od najvećih poduzeća te vrste u Hrvatskoj, koje je radilo samo šest godina. U članku je vidljiva autoričina marksistička interpretacija djelovanja toga poduzeća. ${ }^{70}$ Ona tvornicu vidi kao tipični „proizvod poslijeratne konjunkture, kad su spretni bankarci u privatnim lokalnim bankama i advokati 'lovili u mutnom' i izmanipulirali posjednike malih kapitala na području Hrvatskog zagorja pomoću dionica, a radništvo Krapine i njegove okoline pomoću niskih zarada i velike eksploatacije” (str. 57). Pogon je 1925.

\footnotetext{
${ }^{69}$ Od ovoga broja javljala se kao autorica s druge akademske institucije - Filozofskoga fakulteta Sveučilišta u Zagrebu.

${ }^{70}$ „Ta je tvornica tipičan proizvod poslijeratne konjunkture u kojoj su bile upotrijebljene sve mogućnosti kako bi bogati postali još bogatiji iskorištavanjem brojnih sitnih kapitala Zagoraca i grubom eksploatacijom slabo plaćenih radnika" (str. 51).
} 
izgorio u požaru, a na njegovu zgarištu poslije je osnovana nova velika tvornica tekstila, koja je po broju radne snage ubrzo premašila svoju prethodnicu.

Godine 1989. ČSP je objavio prvi od dva trobroja u svojem dugogodišnjem izdavanju. ${ }^{71}$ I u njemu je dotaknuta ekonomska povijest, i to u izvornom znanstvenom članku Darka Dukovskoga „Socijalno-ekonomska i politička previranja među prosvjetnim radnicima u Istri neposredno nakon prvog svjetskog rata (1919-1923)". Dukovski, tada djelatnik Muzeja narodne revolucije Istre, sam u uvodu naglašava da je taj članak povijesna studija koja sadržava tri pomoćne znanosti - sociologiju, ekonomiju i politologiju. Pritom treba reći da je ekonomskoga dijela najmanje jer ako se isključi povijest rada, u članku od ekonomije ostaje samo nekoliko rečenica o ekonomskoj krizi toga vremena.

U tom trobroju izvorni znanstveni članak napisao je i Vilim Ribić - „Koncepcija prvobitne socijalističke akumulacije u Jugoslaviji (razdoblje četrdesetih i pedesetih godina - 1945-1954)". U članku koji sasvim spada u domenu ekonomske povijesti Ribić razmatra promjenu koncepta socijalističke akumulacije nakon uvođenja samoupravnoga principa u ekonomiju. Zaključuje da je „objektivna prisutnost tržišta i samoupravljanja bila nedovoljna da bi se sistem mogao okarakterizirati kao samoupravni. Prvobitna socijalistička akumulacija zahtijeva državu u privredi, a budući da država mora angažirati svoj aparat, birokratizam, bez obzira na njegove demokratskije forme nego u staljinizmu, nije se mogao izbjeći” (str. 127).

Godine 1990. objavljena su dva članka. U dvobroju 1-2 Mira Kolar-Dimitrijević objavila je pregledni članak „Istraživanja društveno-političkih i ekonomsko-socijalnih prilika na području Požeške kotline (radovi Filipa Potrebice)". U fokusu su radovi povjesničara Filipa Potrebice, koji se tada već više od četvrt stoljeća bavio istraživanjima društvene, gospodarske i kulturne prošlosti Požege i požeškoga kraja. Autorica naglašava da Potrebica u svim svojim radovima „polazi od društveno-ekonomske komponente kao odlučnog faktora razvoja” (str. 237-238) i da je svojim radovima "dokazao nužnost povezivanja povijesti s regijama i njihovom privredom” (str. 243).

U trećem broju 1990. Zdenka Šimončić-Bobetko objavila je izvorni znanstveni članak „Gospodarstvene prilike u sjevernoj Hrvatskoj u godinama poslije prvoga svjetskog rata”. U radu obogaćenom brojnim tablicama i statističkim prilozima autorica je prikazala stanje gospodarstva sjeverne Hrvatske. Najviše prostora dala je poljoprivredi s obzirom na činjenicu da je to bila temeljna oblast privređivanja većine stanovništva i da je u socijalno-ekonomskoj strukturi bila dominantna (od poljoprivrede je tada živjelo 3/4 ukupnoga stanovništva). Obrt, industrija, trgovina i bankarstvo bili su nešto više razvijeni na području tzv. uže Hrvatske, ali zato mnogo slabije u pasivnim gorskim krajevima. Proces smanjivanja poljoprivrednoga stanovništva na tom je prostoru tekao

${ }^{71}$ Drugi trobroj objavljen je 1991. godine. Ovi podaci o gubitku standardnoga ritma objavljivanja odraz su burnih i prijelomnih godina ne samo za povijest $\check{C} S P$-a nego i Instituta, ali i društva općenito. 
vrlo sporo jer industrija i ostale djelatnosti izvan poljoprivrede nisu pratile demografski razvitak.

U drugom broju za 1992. objavljena su tri znanstvena rada. Prva dva napisala je Mira Kolar-Dimitrijević. Radi se o izvornim znanstvenim člancima „Presjek kroz rad Zagrebačke pivovare d.d. do 1945. godine” i „Zagrebačka tvornica kavinih proizvoda Franck do 1945. godine". Prikazujući na početku povijest pivarstva u Hrvatskoj, autorica ističe da su obrtnici pivari u Zagrebu postojali još u XIV. stoljeću. Ideja o osnivanju velike moderne pivovare u Zagrebu niknula je u krugu Hrvatske eskomptne banke još 1890., a pivovara je osnovana 1892. godine. Nakon početnoga uspjeha pivovara je upala u krizu sve dok nije postala privatno poduzeće židovske obitelji Alexander. Prema autorici, pivovara je „izvanredan [...] primjer domaćega industrijskog poduzetništva koje se uspjelo održati zahvaljujući umješnosti glavnog vlasnika (Samuila Davida Alexandera) i kvaliteti robe, unatoč presiji državnih vlasti” (str. 149). U drugom članku Kolar-Dimitrijević nastojala je u povodu stogodišnjice Zagrebačke tvornice Franck naznačiti najvažnija kretanja u njezinu razvoju do 1945. godine. I taj rad nastavak je njezina istraživanja povijesti tvornica, s time da je u svjetlu demokratskih promjena koje su se dogodile početkom 1990-ih sada istaknula jedan metodološki problem koji prije nije isticala. Naime, rad otvara konstatacijom da je vrlo teško pisati povijest tvornica, pogotovo na prostoru bivše Jugoslavije.

„Socijalizirana privreda poslije 1945. nastojala je negirati svaki doprinos osnivača i vlasnika razvoju tvornice, pa su oni ne samo razvlašteni materijalno, već im je oduzeta i povijesna uloga. Kako se gledalo na povijest poduzeća još prije nekoliko godina, pokazat ću na primjeru 'Jugorapida'. To je zapravo tvornica turpija Faber, osnovana u Zagrebu još 1855. godine. S dr. Dragutinom Feletarom napisala sam po narudžbi firme monografiju 'RO Jugorapid 1855-1985' (Zagreb 1986.) u kojoj je prikazan napor generacija obitelji Faber da se ovo poduzeće razvije i održi. Iako je knjiga izišla, nikada nije promovirana" (str. 169).

U nastavku je naglasila da je s druge strane u zapadnoj Europi takva historiografija bila institucionalizirana.

„I dok smo mi tako radili pod embargom, u Njemačkoj još od 1976. djeluje posebno društvo za povijest poduzeća, ${ }^{[72]}$ koje iz prošlosti izvlači savjete za rad poduzeća u suvremenosti, te ima izuzetno značenje za korekciju ponašanja poduzeća na europskom i svjetskom planu" (str. 169).

Pored same tvornice, dala je i kratak pregled razvoja industrije kave u svijetu i u nas. Tako saznajemo i da je prva manufaktura cikorije (biljke koja se u Europi koristila kao jeftinija zamjena za pravu kavu) kod nas osnovana u Varaždinu. Johann Heinrich Franck, njemački poduzetnik koji je po Austro-

72 O tom društvu opširnije je pisala u članku „O radu njemačkoga društva za povijest poduzeća”. 
Ugarskoj Monarhiji otvarao brojne tvornice cikorije, jednu je otvorio i u Zagrebu krajem 1892. godine. Kao vlasnici su bili upisani njegovi sinovi Wilhelm, Hermann, Gustav, Karl i Robert Franck, koji su zajednički vodili poduzeće iako su neki živjeli u Linzu, a neki u Ludwigsburgu, gdje je i dalje bila centrala toga obiteljskog poduzeća (str. 172). Nakon raspada Austro-Ugarske nova je država (Kraljevina Srba, Hrvata i Slovenaca) bila netolerantna prema Austrijancima i Nijemcima, pa su i Franckovi smatrani podanicima neprijateljskih država. Tvornica otada više nije bila dio njemačkoga koncerna. Za glavnoga upravitelja postavljen je Josip Hrabovsky iz Beograda kao vladina osoba od povjerenja. Prognani njemački kapital nakon Prvoga svjetskog rata zamijenjen je francuskim, engleskim i češkim, a poslije velike svjetske krize došlo do ponovnoga jačanja njemačko-austrijskoga kapitala. Tvornica je postala dio velikoga njemačkoga koncerna Internationale Nahrungs- und Genussmittel A.G. i za vrijeme Drugoga svjetskog rata proizvodila je uglavnom za vojne potrebe. Nakon rata je prešla u državno vlasništvo.

Autor trećega relevantnog rada u 1992. bio je Boris Olujić. U stručnom članku pod naslovom „Dva jubileja Trgovačko-obrtničke komore u Zagrebu” dao je kratak pregled povijesti Hrvatske gospodarske komore u Zagrebu, koja je slavila 140 godina postojanja. Analizirajući godišnjake Komore, autor je prikazao povijesnu dimenziju slavljenja 50. i 70. godišnjice njezina postojanja.

U dvobroju (br. 2-3) 1993. objavljen je izvorni znanstveni članak Mire Kolar-Dimitrijević „Gospodarstvo kao sredstvo političke prisile: U povodu šezdesete godišnjice Josipa Predavca”. U njemu se obrađuje rad i slom gospodarskih ustanova Hrvatske seljačke stranke - Seljački dom, Središnji savez hrvatskih seljačkih zadruga, osiguravajuća zadruga „Providnost” i Hrvatska seljačka zadružna banka - u kojima je Josip Predavec bio vodeća ličnost. Autorica je istaknula da je rad tih organizacija bio analiziran na suđenju Predavcu 1930., dakako u potpuno negativnom kontekstu, i da je stoga „potrebno tu analizu korigirati, te objektivno prikazati kako i kojim sredstvima su poslovali ti zavodi, koji su se slomili pod pritiskom beogradske gospodarske politike" (str. 203). Predavec, prema Kolar-Dimitrijević stvarni realizator gospodarske politike Hrvatske seljačke stranke, osudom za privredni kriminal nepravedno je eliminiran i s političke i s gospodarske scene, a članstvo stranke ostalo je bez svojih važnih gospodarskih zavoda i zapalo u velike poteškoće. Istaknula je da je članak napisala u povodu 60. godišnjice Predavčeve smrti.

Ista autorica nastavila se baviti za gospodarsku povijest znamenitim osobama, a obljetnička motivacija i dalje je bila prisutna. Tako je u drugom broju za 1994. objavila izvorni znanstveni članak „O zagrebačkom gospodarstveniku Vjekoslavu Heinzelu, 1871.-1934.” Godine u kojoj je grad Zagreb slavio svoju 900. obljetnicu navršilo se točno 60 godina od Heinzelove smrti, što je autorica smatrala prigodom „da se o Heinzelu kaže istina i da se ukaže na njegovu veličinu kao tvorca modernog Zagreba i vrlo uspješnog djelatnika pri procesu uključivanja Zagreba i Hrvatske u srednju Europu” (str. 257). Arhitekt po struci, Heinzel je bio i uspješan gospodarstvenik, tj. član mnogih dioničkih 
poduzeća i komunalnih ustanova, deset godina bio je predsjednik Trgovačke i obrtničke komore, a osam godina zagrebački gradonačelnik.

Radove iz ekonomske povijesti u ČSP-u 1995. objavila je samo Mira Kolar-Dimitrijević: najprije u prvom broju prikaz knjige Danice Božić-Bužančić Južna Hrvatska u europskom fiziokratskom pokretu. Pokret za obnovu gospodarstva, gospodarske akademije, ogledni vrtovi i poljodjelske škole druge polovice XVIII. i početka XIX. stoljeća (Split, 1995.), a potom u trećem broju izvorni znanstveni članak „Hrvatsko gospodarstvo u Nezavisnoj Državi Hrvatskoj”. Zavisnost od Hitlerova Trećega Reicha i Mussolinijeve Italije u znatnoj je mjeri utjecala na razvoj gospodarstva Nezavisne Države Hrvatske (NDH). ${ }^{73}$ Ona je „imala zadaću da upotpuni njemački Grosswirtschaftsraum i da omogući Hitleru laku opskrbu sirovinama, žitaricama i radnom snagom. Podjela NDH na interesne sfere između Trećeg Reicha i Mussolinijeve Italije bila je načinjena uglavnom prema interesima eksploatacije njezinih bogatstava. Pretjerani zahtjevi Njemačke i Italije s obzirom na isporuku boksita, željezne rudače, drva, žita i radne snage uzrokovali su velike probleme, koje NDH nije mogla riješiti, jer je narod te zahtjeve ocijenio kao fašističke i pružio organizirani otpor u antifašističkoj borbi” (str. 527-528). Autorica tome kao dodatnu otežavajuću okolnost dodaje i destrukciju gospodarstva koja je započela djelovanjem partizana i drugih čimbenika te zaključuje da je usprkos tome gospodarstvo $\mathrm{NDH}$ uspjelo u nekim područjima ostvariti pozitivne rezultate, a osobito je zanimljivim smatrala samu organizaciju i planove za razvoj gospodarstva.

U dvobroju (br. 1-2) 1996. Jasna Turkalj javila se svojim jedinim za ekonomsku povijest relevantnim radom objavivši izvorni znanstveni članak „Gospodarska problematika u listu Hervatska 1871. godine”, u kojem se bavi gospodarskim prilikama u Banskoj Hrvatskoj i Vojnoj krajini 1871. na temelju analize članaka u pravaškom glasilu Hervatska. Premda izrazito politički list, u kojem članci o gospodarskim temama nisu bili brojni, Hervatska je upozoravala i na goruće probleme gospodarstva u trgovini, obrtu, prometu, eksploataciji krajiških šuma te agrarnim odnosima, tretirajući ih, u skladu s pravaškim koncepcijama, u najužoj vezi s državno-pravnim položajem Banske Hrvatske i Vojne krajine. Zastupajući motrište da je gospodarski prosperitet nemoguć sve dok hrvatski narod ne bude imao svoju samostalnu i nezavisnu državu u kojoj će gospodarstvo uređivati i razvijati prema vlastitim interesima i potrebama, korijene lošega stanja u gospodarstvu list je vidio u od vlasti ustrojenom, neodgovarajućem obrazovanju hrvatske mladeži.

Godine 1998. Mira Kolar-Dimitrijević objavila je nova dva članka iz sfere gospodarske povijesti. U drugom broju objavljen je pregledni rad „Podružnica Hrvatskog Radiše u Gospiću 1920.-1921. godine”, u kojem je na osnovi tiska pokušala rekonstruirati osnivanje podružnice toga društva koje je inicijalno imalo misiju smještanja i naukovanja siromašne djece kod hrvatskih obrtnika

73 Autorica navodi da su se na području koje je Rimskim ugovorima 18. svibnja 1941. bilo ustupljeno Italiji, prema podacima industrijskoga katastra Hrvatskoga državnoga družtvovnogospodarskog zavoda iz 1939., nalazila 124 industrijska poduzeća sa 150 tvornica (str. 527). 
u Zagrebu nakon Prvoga svjetskog rata. Autorica zaključuje da je društvo imalo znatan uspjeh bez obzira na opstrukcije monarhističke vlasti. U istom broju objavljen je i prikaz Petra Strčića „Tri knjige Jakova Sirotkovića o gospodarskoj osnovi propasti SFR Jugoslavije i velikosrpske agresije na Hrvatsku”. Prikazane su knjige: Hrvatsko gospodarstvo 1945-1992. Ekonomski uzroci sloma Jugoslavije i oružane agresije na Hrvatsku (Zagreb, 1993.), Hrvatsko gospodarstvo. Privredna kretanja i ekonomska politika (Zagreb, 1996.) i Memorandum SANU iz 1995. godine. (Kritički osvrt na knjigu K. Mihailovića i V. Krestića „Memorandum SANU”, odgovori na kritike) (Zagreb, 1996.).

U trećem broju 1998. Mira Kolar-Dimitrijević objavila je izvorni znanstveni članak „Belje između dva svjetska rata. Uloga politike u organizaciji beljskog gospodarstva od 1918. do 1941. godine”. Belje je bilo jedno od najvećih poljoprivrednih imanja Srednje Europe. Nastalo je 1698. i nakon četvrt tisućljeća pod okriljem carske kuće Habsburg došlo je većim dijelom pod novu jugoslavensku državu. Podjelom dobra između Mađarske i jugoslavenske države nakon Prvoga svjetskog rata, ono se teško prilagođavalo novim uvjetima. Naime, sva industrijska poduzeća ostala su na jugoslavenskoj strani, a livade i oranice na mađarskoj. Autorica smatra da je „zbog izvanredne pljačke tijekom prvih četiriju godina nakon završetka Prvog svjetskog rata” Belje pokazivalo negativnu bilancu iako je to bilo vrijeme prosperiteta za poljoprivredne proizvođače u cijeloj jugoslavenskoj državi, „što znači da se na Belje gledalo kao na ratni plijen, a ne kao na gospodarstvo budućnosti i uzorno imanje" (str. 523). Autorica pokazuje koliki je politika imala utjecaj u upravljanju tim dobrom. Belje je de facto postalo dvorski posjed, iako se to nastojalo prikriti njegovom pripadnošću pod razna ministarstva i generalnu direkciju u Beogradu. Njegove bilance uvijek su nejasne i netočne, a njegovi ravnatelji ljudi bliski dvoru. Tek nakon smrti kralja Aleksandra uprava Belja dobiva nešto više samostalnosti, zaključila je autorica.

Ona je u drugom broju za 1999. objavila i stručni članak „Projekt povijesti Zagrebačkog velesajma iz 1967. godine (u povodu 90-godišnjice Velesajma)”, u kojem je nastojala odgovoriti na pitanje zašto do svoje 90. godišnjice, koja se navršila 1999., ${ }^{74}$ Zagrebački velesajam nije dobio pravu povijesnu monografiju. Pritom je upozorila na dva važnija pokušaja da se povijest napiše, a osobita se pozornost posvećuje drugom projektu iz 1967., koji je nastao u okviru Instituta za historiju radničkog pokreta Hrvatske. Tekstovi toga projekta doneseni su u članku. Kao jedan od razloga zašto projekt nije bio realiziran autorica navodi da su isticanje Zagreba kao nekadašnjega najjačega gospodarskog središta i rezultata suvremenih istraživanja koji su upućivali na njegovo zaostajanje u socijalističkoj Jugoslaviji bili „suviše provokativni za tadašnje političke rukovodioce Hrvatske" (str. 322).

${ }_{74}$ Zagrebački velesajam svoj početak baštini od 1909., kad je osnovan pod nazivom Zagrebački zbor. 
U istom broju objavljen je i izvorni znanstveni članak Seke Brkljače „Bosanskohercegovački boksit kao strateška sirovina (1918.-1945.)”. Ona je prikazala tada poznata nalazišta ruda i važnost bosanskohercegovačkoga boksita kao strateške sirovine. Bosanskohercegovački je boksit 1937. činio 45,5 \% produkcije boksita tadašnje Kraljevine Jugoslavije. Do 1941. Bosna i Hercegovina imala je pedesetak poznatih nalazišta boksita. Posebno je prikazano razdoblje pojačanoga interesa i potražnje Njemačkoga Reicha za tom sirovinom, koji je brzo preuzeo čitavu bosanskohercegovačku produkciju te rude.

U trećem broju 1999. Mato Artuković objavio je izvorni znanstveni članak „Srpska gospodarska, kulturna, prosvjetna i humanitarna društva”, u kojem prikazuje društva koja su stvarali Srbi u Hrvatskoj od 1883. do 1903. godine. Za gospodarsku povijest važni su podaci koje donosi o ekonomskim institucijama. U tom razdoblju Srbi su osnovali Srpsku banku, više zemljoradničkih zadruga, 56 različitih novčanih zavoda te ekonomsku organizaciju „Privrednik”. Artuković nastoji odgovoriti na pitanje „kako se, na koji način i u kojoj mjeri identificira srpski narod s društvima koja stvara?” Ta društva on vidi kao „pouzdan štit identiteta jednoga naroda” (str. 491).

U istom broju Damir Matanović objavio je prikaz knjige Zlate ŽivakovićKerže $S$ tradicionalnih na nove puteve (Trgovina, obrt, industrija i bankarske ustanove grada Osijeka na prijelazu stoljeća od godine 1868. do 1918.) (Osijek, 1999.).

Za razliku od 2000., kada osim prikaza knjige Stjepana Sršana Tvrtke u istočnoj Slavoniji: memorandumi od sredine 19. do sredine 20. stoljeća (Osijek, 1998.) iz pera Borislava Bijelića nije objavljen nijedan članak, 2001. bila je rekordna godina po broju radova iz ekonomske povijesti. Najprije je u drugom broju objavljen izvorni znanstveni članak Ivice Goleca „Obrtničko-radničko društvo 'Banovac' u Petrinji (1885.-1905.)”, koji je prikazao djelovanje toga društva od njegova osnivanja do posvete nove zastave 1905. godine. Autor iznosi podatke iz kojih je vidljivo da je to vrijeme najvećih uspjeha društva, u kojemu je ono dalo znatan doprinos razvoju obrtništva Petrinje i Banovine.

Povećan broj radova iz ekonomske povijesti 2001. vezan je za I. kongres hrvatskih povjesničara, koji je održan od 9. do 10. prosinca 1999. u Zagrebu. Jedna od sekcija na kongresu djelovala je pod nazivom "Gospodarska povijest”, ${ }^{75}$ a u trećem broju ČSP-a za 2001. objavljena su četiri rada s te sekcije. Mira KolarDimitrijević, kao moderatorica sekcije, napisala je kratku uvodnu obavijest u kojoj je napomenula „da je ekonomska povijest u 'velikim historiografijama' vrlo razvijena i plodna, da ima svoje institute i svoje znanstvene skupove”, a da u nas nema dovoljno suradnje povjesničara, ekonomista i pravnika „iako bi se samo tako mogli postići bolji i brži rezultati u istraživanju vrlo zanimljive gospodarske povijesti hrvatskih prostora" (str. 839).

U članku „Veterinarska povijest Hrvatske kao znanstveni projekt gospodarske povijesti", koji je kategoriziran kao prethodno priopćenje, Vesna Vuče-

${ }^{75}$ Vidi ovdje bilj. 58 . 
vac-Bajt dala je pregled razvoja veterinarstva u Hrvatskoj od najranijih vremena do suvremenosti. Povijest veterinarstva prikazana je kao neizostavan i bitan dio gospodarske povijesti Hrvatske jer se, prema autorici, veterinarstvo uvijek prilagođavalo gospodarstvenim promjenama.

Zlatko Virc u svojem je kratkom referatu „Izvori za gospodarsku povijest na primjeru Brodske imovne općine u Vinkovcima", koji je izložio na skupu (kategorizacija: izlaganje sa skupa), prikazao fond Brodske imovne općine koji se čuvao u Arhivskom sabirnom centru Vinkovci Državnoga arhiva u Osijeku. Naglasio je da su dokumenti Brodske imovne općine važan izvor za proučavanje gospodarske povijesti cjelokupne Vojne krajine s obzirom na to da nisu sačuvani fondovi drugih imovnih općina iz Vojne krajine.

U članku (prethodno priopćenje) „Analiza regionalnih gospodarskih povijesnih radova na primjeru Podravine (Ludbreške, Koprivničke i Đurđevačke)" Hrvoje Petrić analizirao je regionalne gospodarsko-povijesne radove na primjeru Podravine, valorizirajući njihovu vrijednost te mogućnosti daljnjih istraživanja gospodarske povijesti podravskoga kraja. Zaključio je da taj prostor ima bogatu gospodarsku povijest koju su obrađivali deseci autora (povjesničari, geografi, publicisti) u tekstovima različite znanstvene vrijednosti. Upozorio je na potrebu analitičkoga pristupa u novim detaljnim istraživanjima, kao i na potrebu pisanja moderne gospodarske povijesne sinteze te regije.

Ivica Šute prikazao je u članku (prethodno priopćenje) „Gospodarska povijest u školskim udžbenicima od 1945. do 1999. godine” koliki je prostor bio posvećen gospodarskoj povijesti u osnovnoškolskim i gimnazijskim udžbenicima povijesti te kakav se pristup gospodarskoj povijesti primjenjivao u promatranom razdoblju. Ustvrdio je da je do 1990. prevladavao marksističko-materijalistički pristup svojstven socijalističkom političkom sustavu koji je tada vladao. Nakon 1990. taj je pristup napušten, ali je zaključio da se „neke veće konceptualne i kvantitativne promjene glede gospodarske problematike u udžbenicima nisu dogodile" (str. 879). Iste je godine u trećem broju objavljen prikaz knjige Jere Jareba, Državno gospodarstveno povjerenstvo Nezavisne Države Hrvatske od kolovoza 1941. do travnja 1945. (Zagreb 2001.) iz pera Hrvoja Matkovića.

Godine 2002. i 2003. nije objavljen nijedan članak osim dva prikaza Milana Vrbanusa 2002. godine. Prvi je prikaz promocije knjige akademika Vladimira Stipetića Povijest hrvatske ekonomske misli (1298.-1847.) (Zagreb, 2001.), koji je objavljen u prvom broju, a u trećem je broju prikazao i samu Stipetićevu knjigu.

U trećem broju 2004. Nikola Mijatović objavio je izvorni znanstveni članak „Usklađivanje europskog PDV-a - povijesni prikaz”. U radu se najprije daje prikaz rada porezne i financijske komisije pod vodstvom Fritza Neumarka (tzv. Neumarkova komisija), čiji je zadatak bio pronaći načine usklađivanja posrednih poreza koji postoje u poreznim sustavima država članica Europske ekonomske zajednice (poslije Europske unije). Komisija osnovana 1960. trebala je ustanoviti postoje li razlike u javnim financijama država članica i 
„ako postoje u kojem opsegu predstavljaju smetnju ili čak onemogućavaju zajedničko tržište i, drugo, koje mogućnosti postoje kako bi se otklonile razlike koje ometaju izgradnju i funkcioniranje zajedničkog tržišta" (str. 964). Zatim se pobliže obrađuje tijek uvođenja poreza na dodanu vrijednost (PDV) u europske zemlje, kao i izgradnja europskoga sustava PDV-a i harmonizacija njegove porezne osnovice. Posebna se važnost pritom pridaje Prvoj, Drugoj i Šestoj smjernici PDV-a. Navode se i razni prijedlozi Komisije za prevladavanje problema neusklađenosti PDV-a u europskim državama, a detaljnije se obrađuje prijelazno rješenje europskoga sustava PDV-a koje je tada bilo na snazi.

U istom broju Nikica Barić objavio je prikaz knjige Nikole Žutića Avio-industrija i vazduhoplovstvo u Kraljevini Jugoslaviji 1918-1945 (Beograd, 2004.).

Godine 2005. objavljen je jedan članak i tri prikaza. Goran Arčabić i Iva Kraljević u drugom su broju objavili izvorni znanstveni članak „Uloga listova 'Privreda Zagreba' i 'Zagrebačka panorama' u gospodarskom i društvenom životu Grada između 1954. i 1966. godine”. Autori nastoje odrediti ulogu tih listova u gospodarskom i društvenom životu Zagreba u razdoblju kada je odlukom državnoga vrha Federativne Narodne Republike Jugoslavije usporen proces demokratizacije i debirokratizacije hrvatskoga (jugoslavenskoga) društva. „Časopisi Privreda Zagreba i Zagrebačka panorama funkcionirali su kao mediji Narodnog odbora grada Zagreba u vremenu intenzivne gospodarske i infrastrukturne izgradnje te kulturnog i znanstvenog uspona grada između 1954. i 1966. godine. Privreda Zagreba isprva je bila usko orijentirana na gradsku gospodarsku problematiku (ponajviše na razvoj industrije)" (str. 405).

U istom broju Milan Vrbanus donio je informacije s predstavljanja Biblioteke „Hrvatska ekonomska misao”. U trećem broju te godine isti autor objavio je prikaz knjige Imbre Ignjatijevića Tkalca Hrvatsko gospodarstvo polovicom XIX. stoljeća (Zagreb, 2004.), a Danijel Vojak prikazao je prvi broj novoosnovanoga časopisa Ekonomska i ekohistorija: časopis za gospodarsku povijest i povijest okoliša.

Godine 2007. objavljena su tri članka iz sfere ekonomske povijesti. U prvom broju Tomislav Anić objavio je izvorni znanstveni članak „Normativni okvir podržavljenja imovine u Hrvatskoj/Jugoslaviji 1944.-1946.” Marksistička teorija i sovjetski model upravljanja kojim su se nadahnjivali jugoslavenski komunisti nalagali su princip kolektivnoga vlasništva i državnoga poduzetništva. Komunistička partija Jugoslavije podržavljivala je imovinu da bi ovladala privredom kao najvažnijim državnim sektorom. Anić je istražio mjere provedene u svrhu podržavljenja imovine u Hrvatskoj/Jugoslaviji. Analizirao je odnos Komunističke partije Jugoslavije prema pitanju vlasništva prije rata, za vrijeme rata i neposredno nakon njegova završetka te stvaranje preduvjeta za podržavljenje imovine. Podržavljenje, koje je u svojoj biti bilo klasnoga karaktera, provodilo se kroz tri instituta: konfiskaciju, sekvestraciju i nacionalizaciju. „Imovina se oduzimala pod izgovorom suradnje s okupatorom, a zakoni doneseni u tu svrhu pružali su mogućnost najšire interpretacije tog termina" (str. 61). 
U istom broju Zlata Živaković-Kerže u članku „Podržavljenje imovine Židova u Osijeku u NDH" analizirala je kako je NDH provodila podržavljenje nepokretne i pokretne imovine Židova u Osijeku od 1941. do 1943. godine. Autorica je donijela i popis podržavljene nepokretne imovine. Iz toga popisa jasno se uočava prijeratna gospodarska djelatnost Židova u Osijeku. Saznajemo da se $52 \%$ prijeratnih osječkih Židova bavilo trgovinom, 26 \% obrtom, $15 \%$ posjedovalo je nekretnine i kuće, a $7 \%$ bili su industrijalci i ugostitelji. Prema autorici, vlasti NDH smatrale su da će podržavljenjem židovske imovine "nacionalno gospodarstvo osloboditi od dominacije židovskih industrijalaca, trgovaca, obrtnika i vlasnika nekretnina. No, unatoč zamišljenome preobrazba gospodarstva u NDH nije uspjela jer je u neizgrađenoj i nesigurnoj državi podržavljen židovski imetak bio izložen otimanju i propadanju" (str. 115).

U drugom broju 2007. Tomislav Jonjić objavio je izvorni znanstveni članak „Sudbina švicarske imovine u Nezavisnoj Državi Hrvatskoj, 1941.-1945.,, u kojem je na temelju gradiva Švicarskoga konzulata u Zagrebu prikazao kako se štitila švicarska imovina u NDH. Iako ju Švicarska nije priznala, NDH je pružila veliku pomoć Švicarskom konzulatu da spasi najveći dio robe koja se u Travanjskom ratu zatekla na hrvatskom području. I pri zaštiti švicarskoga kapitala vlasti NDH nastojale su naći kompromis između vlastitih interesa, prava švicarskih vlasnika i presizanja njemačke države i njemačkoga kapitala. Prema autoru, u velikoj većini slučajeva otvorena su pitanja riješena „na obostrano, i hrvatsko i švicarsko zadovoljstvo" (str. 385). No zanimljiv je podatak da je NDH tijekom 1941. i 1942. uspjela u Švicarsku izvesti osjetno više robe nego što je uvezla, zbog čega je dolazilo do nezadovoljstva švicarske strane i političkih trzavica između dviju država.

Što se događalo sa švicarskim kapitalom i poduzećima nakon Drugoga svjetskog rata tema je koja je djelomično obrađena i u ČSP-u. Tomislav Anić nastavio je rad na tematici podržavljenja i u 2008., kad je u trećem broju objavljen njegov izvorni znanstveni članak „Podržavljenje stranog kapitala u Hrvatskoj/Jugoslaviji 1945.-1946. na primjeru poduzeća Thonet Mundus d.d. u većinskom švicarskom vlasništvu”. U radu je prikazao postupak podržavljenja toga poduzeća opisujući prije svega pravni aspekt problema prelaska švicarske imovine u državno vlasništvo. U poraću je vlasništvo nad gospodarskim subjektima bilo važno novoj komunističkoj vlasti jer im je osiguravalo opstanak na vlasti. Početak razvlašćivanja vlasnika krupnoga kapitala bio je zamašnjak koji je osiguravao postojanje samoga sustava zato što se znatan dio kapitala i industrijskih postrojenja prije rata nalazio u vlasništvu stranaca. U cjelokupnoj industriji strani je kapital sudjelovao sa 49,51 \%, no u najdohodovnijim granama njegov je udio bio znatno veći, primjerice 90,9\%, ili 73,6 \% u kemijskoj industriji (str. 819). Taj članak pokazuje i da je nova vlast u podržavljenju drugačije tretirala domaće gospodarske subjekte od onih koji su bili u stranom vlasništvu, kao i da su se drugačije tretirali strani vlasnici koji su bili iz zemalja koje su smatrane okupatorima od onih iz država koje su bile neutralne ili savezničke. 
Sljedećih nekoliko godina vladalo je najduže zatišje u obradi gospodarskih tema u ČSP-u. Idući znanstveni članak bit će objavljen tek 2013. godine. U tom je razdoblju objavljeno samo nekoliko prikaza o gospodarskim temama. U drugom broju 2010. Antonio Gotovac prikazao je hrvatsko izdanje uspješnice Nialla Fergusona Uspon novca. Financijska povijest svijeta (Zagreb, 2009.), a u trećem broju Stipica Grgić knjigu Ivice Šutea Slogom slobodi! Gospodarska sloga 1935.-1941. (Zagreb, 2010.).

Godine 2013. objavljena su tri prikaza i jedan članak. Maja Crnjac u prvom je broju prikazala knjigu Vladimira Ivanovića Geburtstag pišeš normalno. Jugoslovenski gastarbajteri u SR Nemačkoj i Austriji 1965.-1973. (Beograd, 2012.). Lidija Bencetić u drugom broju prikazala je knjigu Marina Manina i Željke Pinjuh Ćorić 150 godina zagrebačke plinare 1862.-2012. (Zagreb, 2012.) te knjigu Ivána T. Berenda Ekonomska povijest Europe dvadesetog stoljeća. Ekonomski režimi od laissez-fairea do globalizacije (Zagreb, 2011.). Jedini članak te godine objavio je Marko Miljković. U drugom broju kao izvorni znanstveni rad objavljen je pod naslovom „Sajmovi automobila u Kraljevini Jugoslaviji kao mjesta promidžbe nacističke Njemačke”. Autor je najprije pokazao da su sajmovi automobila u nacističkoj Njemačkoj imali značenje koje je uvelike nadilazilo okvire gospodarske manifestacije jer su služili kao važno sredstvo nacističke promidžbe. Potom je analizirao gospodarsku suradnju dviju zemalja tridesetih godina, pogotovo izvoz njemačkih automobila u Kraljevinu Jugoslaviju tijekom druge polovine 1930-ih. Usporedbom nastupa njemačke automobilske industrije na sajmovima automobila u Beogradu, Zagrebu i Ljubljani u drugoj polovini 1930-ih autor je analizirao na koji su način i u kojoj mjeri te manifestacije u Kraljevini Jugoslaviji postale dio mehanizma njemačke nacističke promidžbe. Zaključuje da su njemačke institucije i automobilska industrija na jugoslavenskome tržištu ostvarivale svojevrstan gospodarski nadzor i dominaciju (str. 324).

Godine 2014. objavljena su tri članka i dva prikaza. U drugom broju Vedran Dukovski objavio je izvorni znanstveni članak „Problemi opskrbe i trgovine na području Zone B Julijske krajine u Istri 1945. - 1947. godine”. U analizi su uz probleme trgovine izneseni problemi pojave istarskoga podzemlja, koje se oblikovalo kroz krijumčarenje i postojanje crnoga tržišta. Autor zaključuje da Oblasni narodni odbor za Istru nije mogao zadovoljavajuće riješiti problem opskrbe i trgovine zbog nekoliko razloga, od kojih je prvi bila „politička indoktriniranost komunističkom ideologijom, koja nije dopuštala privatno vlasništvo, ali ni bogaćenje, usprotivivši se zakonima slobodnoga tržišta” (str. 293).

U istom broju Hrvoje Ratkajec objavio je izvorni znanstveni članak „Prostorni vidici industrijalizacije u Istri od 1918. do 1940.: primjeri razvoja rudarske industrije i industrije građevnih materijala”. Autor je iznio ekonomskohistorijsku analizu triju industrijskih grana (eksploatacija boksita i ugljena te proizvodnja cementa) koje su bile među glavnim industrijama na području Istre, $s$ time da je istraživanje ograničio na hrvatski dio poluotoka. Došao je do zaključka da su spomenute industrijske grane bile znatno raspršene u prosto- 
ru, a da su se za transport sirovina i materijala primarno koristile luke. Pritom je, uz bankovne investicije iz Italije, Trst naveden kao važan izvor poduzetničkoga znanja i investicija. Zaključio je i da su u 1930-ima fašistička gospodarska politika i državno vođenje gospodarstva utjecali na usmjerenje tih industrija prema državnoj razini.

U trećem broju Igor Stanić objavio je članak kategoriziran kao prethodno priopćenje pod naslovom „Što pokazuje praksa? Presjek samoupravljanja u brodogradilištu Uljanik 1961-1968. godine”. U toj studiji slučaja autor na primjeru brodogradilišta Uljanik pokazuje na koji je način funkcionirao princip samoupravljanja. Prikazuje djelovanje radničkih savjeta i upravnih odbora kao i poteškoće na koje su ta samoupravna tijela nailazila u svojem radu. Samoupravljanje je formalno u Uljanik uvedeno samo nekoliko mjeseci nakon donošenja tzv. Zakona o predaji tvornica na upravljanje radnicima iz lipnja 1950. godine. U prvih deset godina Uljanikom su upravljali po jedan radnički savjet i upravni odbor na razini brodogradilišta, a od 1961. uvedeni su pogonski radnički savjeti, dok je na razini brodogradilišta ostao i dalje središnji radnički savjet. Autor zaključuje da taj članak potvrđuje rezultate pojedinih istraživanja na razini socijalističke Hrvatske, prije svega kad se govori o problemu nedovoljne kompetentnosti „običnih” radnika za raspravljanje o pojedinim stručnim problemima, kao i o problemu nemotiviranosti radnika za pitanja u kojima nisu vidjeli izravnu osobnu korist. Stanić je u radu prikazao i one za radnike pozitivne aspekte samoupravljanja, zbog čega zaključuje da se radi o kompleksnom i višeslojnom principu te da je „teško donositi jednostran sud o uspješnosti ili neuspješnosti njegova provođenja” (str. 472).

Dunja Melčić objavila je u prvom broju 2014. nešto ekstenzivniji prikaz pod naslovom „Ekonomsko-pravne devijacije i napreci iz sistemskog motrišta”, u kojem se osvrnula na studiju Brune Schönfeldera Vom Spätsozialismus zur Privatrechtsordnung. Eine Untersuchung über die Interdependenz zwischen Recht und Wirtschaft am Beispiel von Gläubigerschutz und Kredit (Berlin, 2012.). U drugom broju Margareta Matijević prikazala je knjigu bosanskohercegovačke povjesničarke Vere Katz Društveni i ekonomski razvoj Bosne i Hercegovine 1945. - 1953. (Sarajevo, 2011.).

Idućih nekoliko godina nije objavljeno mnogo radova iz sfere ekonomske povijesti. Sve do posljednje, 2018., nije bilo nijednoga teksta osim što je Milan Vrbanus u drugom broju 2015. prikazao knjigu Ivice Goleca Razvoj novčanih zavoda na području današnje Sisačko-moslavačke županije 1860. - 1945. (Sisak, 2014.).

Posljednja godina analizirana u ovome pregledu - 2018. - donijela je nove članke iz ekonomske povijesti. Vladan Jovanović objavio je izvorni znanstveni članak „Jugoslavensko-američka opijumska suradnja 1929. - 1941. godine”, u kojem je, na temelju građe Arhiva Jugoslavije, analizirao slabije poznate aspekte američko-jugoslavenskih odnosa tijekom tridesetih godina XX. stoljeća. U tekstu je rekonstruirano nekoliko faza izvoza kvalitetnoga jugoslavenskog, uglavnom makedonskoga sirovog opijuma američkim farmaceutskim kompa- 
nijama. Jugoslavenski je medicinski opijum formalno ušao na američko tržište 1929. ponajviše zahvaljujući propagandi jugoslavenskoga konzulata u New Yorku, pa je već prve godine izvezeno opijuma u vrijednosti oko 21 milijun dinara (str. 41). Od 1929. do 1934. gotovo su čitavu godišnju jugoslavensku proizvodnju otkupljivale američke tvornice. Slijedilo je razdoblje poslovanja tursko-jugoslavenskoga Centralnog biroa, koje je obilježeno međusobnim opstrukcijama i borbom za američko tržište. U trećoj fazi, koja je obilježila razdoblje neposredno prije izbijanja Drugoga svjetskog rata, ilegalna prerada i krijumčarenje droge u Jugoslaviji ugrozili su odnose Jugoslavije i Sjedinjenih Američkih Država.

U istom je broju Nikica Barić prikazao knjigu Ulrike Schult Zwischen Stechuhr und Selbstverwaltung: Eine Mikrogeschichte sozialer Konflikte in der jugoslawischen Fahrzeugindustrie 1965-1985 (Berlin, 2017.).

U radu „Razvoj zadrugarstva na poluotoku Pelješcu u prvoj polovini XX. stoljeća”, objavljenom u drugom broju 2018., Jasenka Maslek prati razvoj zadružnoga organiziranja seljaka na poluotoku Pelješcu od prve zajmovne blagajne, osnovane 1898., do Drugoga svjetskog rata. Autorica daje i pregled gospodarskih prilika u XIX. stoljeću u dubrovačkom okružju i Dalmaciji, s osobitim osvrtom na stanje vinogradarstva i položaj pelješkoga seljaka krajem stoljeća jer je poljoprivreda bila najvažnija gospodarska djelatnost, a vinova loza najraširenija kultura na tom području. Radu je priložen popis zadruga na Pelješcu s prikazom njihove djelatnosti.

\section{Zaključak}

S obzirom na iznesene podatke možemo zaključiti da produkcija Časopisa za suvremenu povijest $\mathrm{u}$ jednom pogledu odražava, ali u drugom i ne odražava stanje hrvatske historiografije. Naime, općenito gledajući, sa svojih manje od $5 \%$ radova posvećenih ekonomskoj povijesti ČSP odražava slabu zastupljenost gospodarske povijesti u hrvatskoj historiografiji. No ako promatramo samu distribuciju tih članaka po godinama objave, onda ČSP ne odražava generalno stanje. Kako smo istaknuli, generalna je ocjena da je devedesetih godina ekonomska historija, slikovito rečeno, „izašla iz mode”. No, u ČSP-u su devedesete desetljeće u kojem je objavljen najveći broj (14) radova iz ekonomske povijesti. To je odraz osobnih afiniteta pojedinih autora, koji su i nakon tektonskih društvenih i političkih promjena na prijelazu iz osamdesetih u devedesete nastavili svoj rad na ekonomskim temama. Pritom jedna znanstvenica - Mira KolarDimitrijević - odskače od svih drugih.

Ona je u ČSP-u, ne samo u devedesetima nego općenito, imala najviše objavljenih radova i prikaza. Trećina svih objavljenih članaka njezino je djelo, a pored toga nitko nije napisao više prikaza o ekonomskim temama od nje. Osim u ČSP-u, objavljivala je radove i u drugim časopisima i od druge 
polovine osamdesetih bila je najplodnija autorica u hrvatskoj historiografiji. Možemo se složiti s opaskom Hrvoja Petrića, koji je istaknuo da je bilo sasvim logično da je upravo ona od Igora Karamana preuzela nastavu iz gospodarske (ali i socijalne povijesti) na Odsjeku za povijest Filozofskoga fakulteta Sveučilišta u Zagrebu. ${ }^{76}$ Možemo zaključiti da je Mira Kolar-Dimitrijević obilježila ČSP kad su u pitanju teme iz ekonomske povijesti.

Teme koje su se obrađivale su raznolike, iz gotovo svih sfera ekonomske povijesti - od poljoprivrede, prometa, trgovine, poduzetništva, pa sve do članaka o samoj metodologiji i teoriji ekonomske historije. Treba naglasiti da i ekonomsko-historijski članci objavljeni u pedeset godišta Č $S P$-a donekle odražavaju promjenu diskursa jer je dominantni marksistički pristup, odnosno interpretacija i istraživački okvir napušten nakon velikih društveno-političkih promjena početkom devedesetih godina XX. stoljeća.

Možemo reći da je ekonomska povijest u hrvatskoj historiografiji dosad dala nekih, čak i važnih rezultata, ali da je generalno ipak na margini naše historiografije. I ovaj pregled pokazuje na dosad u literaturi višestruko istican problem nepostojanja sistemske podrške, odnosno na nedostatak institucionalne infrastrukture i programa u smjeru razvoja ekonomske historije, kao i na nedostatak timskoga i interdisciplinarnoga rada. Nedostaje jača institucionalizacija kroz znanstveno-akademsku infrastrukturu da bi se mogla očekivati neka veća, odnosno osjetnija ostvarenja. Hrvatska nema mnogo ekonomskih povjesničara, pa znanstvena produkcija u tom polju ovisi o entuzijazmu pojedinaca kojih, posljedično, nema mnogo. Možda neke od uzroka takva stanja možemo naći u činjenici da su naši povjesničari slabo ili nikako školovani (usavršeni) da se kvalitetno bave ekonomijom i kvantitativnim metodama. Možda autori druge teme smatraju „lakšima”, ili jednostavno zanimljivijima, pogotovo stoga što su u središtu pozornosti još uvijek „,velike” teme poput političkih odnosa, rata, nacionalnoga pitanja. Indikativno je, a za hrvatsku historiografiju u određenoj mjeri i porazno, da i čak 37 godina nakon što je Mira Kolar-Dimitrijević u ČSP-u konstatirala da će za istraživanje ekonomske povijesti „ubuduće trebati raditi ekipno i znatno sustavnije"77 još vrijedi ista tvrdnja.

\section{Bibliografija radova o ekonomskim temama u Časopisu za suvremenu povijest (1969. - 2018.)}

(1969), br. 1-2

KOLAR-DIMITRIJEVIĆ, Mira. „Proučavanje ekonomsko-socijalne strukture i položaja radničke klase u Hrvatskoj između dva rata u našoj poslijeratnoj literaturi”, 139-179.

(1970), br. 2

KOLAR-DIMITRIJEVIĆ, Mira. „Istraživanja Ive Vinskog s posebnim osvrtom na radove iz ekonomske povijesti međuratnog razdoblja”, 239-247 (prikaz).

76 PETRIĆ, „Prilozi poznavanju historiografije o gospodarskoj povijesti”, 113.

77 KOLAR-DIMITRIJEVIĆ, ,O ekonomsko-socijalnim istraživanjima”, 82. 
(1972), br. 3

KOLAR-DIMITRIJEVIĆ, Mira. „Statistički pregled stranih radnika i članova njihovih porodica u Jugoslaviji 1933. godine", 123-148.

DESPOT, Miroslava. „Igor Karaman, Privreda i društvo Hrvatske u 19. stoljeću, Zagreb 1972. Izd. Sveučilište u Zagrebu - Institut za hrvatsku povijest i Školska knjiga", 183-187 (prikaz).

(1973), br. 1

DESPOT, Miroslava. „Tvornica papira Rijeka, Papir Mills Rijeka, Yugoslavia. Tisak: Athesiadruck Bolzano-Italy (rujan 1971.)”, 210-213 (prikaz).

DESPOT, Miroslava. „Tvornica duhana i ambalaže Rovinj. Fabbrica Tabacchi E Imballaggi Rovigno, Tisak: ČZP 'Primorski tisk' Koper 1972., 213214 (prikaz).

(1973), br. 2

KOLAR-DIMITRIJEVIĆ, Mira. „Ivan Kovačević, Ekonomski položaj radničke klase u Hrvatskoj i Slavoniji 1867-1914, Beograd 1972. Izd. Institut za savremenu istoriju i NIP Export-press, 470 str.", 161-165 (prikaz).

(1973), br. 3

DESPOT, Miroslava. „Dvije monografije o povijesti poduzeća u Hrvatskoj", 201-204 (prikaz).

(1974), br. 1

MATICKA, Marijan. „Proučavanje razvoja poljoprivrede i ekonomsko-socijalnog položaja seljaštva u Hrvatskoj 1918-1941. godine u našoj poslijeratnoj literaturi”, 71-94.

(1975), br. 2

MITTERAUER, Michael. „O položaju ekonomske i socijalne historije u Austriji”, 61-70.

GROSS, Mirjana. „Historija i društvene znanosti”, 71-99.

ŠIMONČIĆ, Zdenka. „Pregled literature i štampanih izvora o industrijskom razvoju Hrvatske u razdoblju između dva svjetska rata”, 101-131.

(1976), br. 1

VINAVER, Vuk. „Svetska ekonomska kriza i jugoslavensko-italijanska trgovina (1930-34)", 39-68.

(1976), br. 2-3

DESPOT, Miroslava. „Bernard Stulli, Prijedlozi i projekti željezničkih pruga u Hrvatskoj 1825-1863, dio 1, i dio 2, Zagreb 1975, Sveučilište u Zagrebu - Institut za hrvatsku povijest, Izvori za hrvatsku povijest, 4/1160 str., 116-120 (prikaz).

(1977), br. 2

BEREND, Iván T. „Uloga ratarske proizvodnje i poljoprivrede u istočnoj i jugoistočnoj Evropi u razdoblju između dva svjetska rata”, 17-36. 
(1978), br. 1

JANJATOVIĆ, Bosiljka. „Josip Zgaljić, Radničkim stazama Riječke rafinerije, Zagreb 1977, 137 str.", 197-198 (prikaz).

JANJATOVIĆ, Bosiljka. „Mira Kolar-Dimitrijević - Zlatko Čepo, INA-Rafinerija nafte Sisak 1927-1977, Sisak 1977, 281 str.", 200-202 (prikaz).

(1978), br. 2

KOLAR-DIMITRIJEVIĆ, Mira. „Obren Blagojević, Naše finansije u periodu narodnooslobodilačke borbe 1941-1945, Beograd 1976, 169 str.”, 115-118 (prikaz).

(1980), br. 2

ČEPO, Zlatko. „Tito - obnovitelj radničkog upravljanja”, 93-114.

(1980), br. 3

KOLAR-DIMITRIJEVIĆ, Mira. „Miroslava Despot, Industrija i trgovina građanske Hrvatske 1873-1880. Prilog gospodarskoj povijesti Hrvatske u doba banovanja Ivana Mažuranića. Građa za gospodarsku povijest Hrvatske, JAZU, knj. 18, Zagreb 1979, 298 str.”, 166-169 (prikaz).

(1982), br. 1

KOLAR-DIMITRIJEVIĆ, Mira. „O ekonomsko-socijalnim istraživanjima”, 80-82.

(1984), br. 2

KOLAR-DIMITRIJEVIĆ, Mira. „Odnos KPJ prema jugoslavenskoj radničkoj emigraciji u međuratnom razdoblju”, 65-83.

(1984), br. 3

ŠIMONČIĆ-BOBETKO, Zdenka. „Ekonomske i posjedovne prilike čabarskog područja i provođenje agrarne reforme između dva rata (19181941)", 53-73.

MILAK, Enes. „Uspostavljanje trgovinskih odnosa između Jugoslavije i Italije 1945-1947. godine", 75-87.

(1985), br. 2

SZABO, Agneza. „Problemi i metode istraživanja društvene strukture nosilaca središnjih (političkih, privrednih i kulturnih) institucija u Zagrebu 1860-1873", 1-36.

(1986), br. 2

KOLAR-DIMITRIJEVIĆ, Mira. „Češko-jugoslavenske veze na privrednoracionalizatorskom i socijalnom području od prvoga svjetskog rata do velike svjetske krize", 1-23.

(1987), br. 1

VALENTIĆ, Mirko. „Društvena i gospodarska struktura Prve banske pukovnije 1848-1881. godine", 19-76. 
LAKIĆ, Zoran. „Branislav Marović, Društveno-ekonomski razvoj Crne Gore 1945-1953, Titograd 1987, 353 str., 202-204 (prikaz).

(1987), br. 2

KOLAR-DIMITRIJEVIĆ, Mira. „'Munja, tvornica akumulatora u Zagrebu od osnivanja do nacionalizacije (1920-1945)”, 81-104.

(1988), br. 1-2

KOLAR-DIMITRIJEVIĆ, Mira. „Zagrebačka tvornica baterija i džepnih svjetiljaka do 1945. godine (Prilog povijesti elektroindustrije Jugoslavije)", 73-93.

(1988), br. 3

KOLAR-DIMITRIJEVIĆ, Mira. „Krapinska tvornica pokućstva i parna pilana d.d. od 1920. do 1925. godine", 51-57.

(1989), br. 1-3

DUKOVSKI, Darko. „Socijalno-ekonomska i politička previranja među prosvjetnim radnicima u Istri neposredno nakon prvog svjetskog rata (19191923)", 29-62.

RIBIĆ, Vilim. „Koncepcija prvobitne socijalističke akumulacije u Jugoslaviji (razdoblje četrdesetih i pedesetih godina - 1945-1954)", 105-127.

(1990), br. 1-2

KOLAR-DIMITRIJEVIĆ, Mira. „Istraživanja društveno-političkih i ekonomsko-socijalnih prilika na području Požeške kotline (radovi Filipa Potrebice)", 237-243.

(1990), br. 3

ŠIMONČIĆ-BOBETKO, Zdenka. „Gospodarstvene prilike u sjevernoj Hrvatskoj u godinama poslije prvoga svjetskog rata”, 21-37.

(1992), br. 2

KOLAR-DIMITRIJEVIĆ, Mira. „Presjek kroz rad Zagrebačke pivovare d.d. do 1945. godine", 149-168.

KOLAR-DIMITRIJEVIĆ, Mira. „Zagrebačka tvornica kavinih proizvoda Franck do 1945. godine", 169-192.

OLUJIĆ, Boris. „Dva jubileja Trgovačko-obrtničke komore u Zagrebu”, 193-201.

(1993), br. 2-3

KOLAR-DIMITRIJEVIĆ, Mira. „Gospodarstvo kao sredstvo političke prisile: U povodu šezdesete godišnjice Josipa Predavca”, 203-224.

(1994), br. 2

KOLAR-DIMITRIJEVIĆ, Mira. „O zagrebačkom gospodarstveniku Vjekoslavu Heinzelu, 1871.-1934., 257-276.

(1995), br. 1 
KOLAR-DIMITRIJEVIĆ, Mira. „Danica Božić-Bužančić, Južna Hrvatska u europskom fiziokratskom pokretu. Pokret za obnovu gospodarstva, gospodarske akademije, ogledni vrtovi i poljodjelske škole druge polovice XVIII. i početka XIX. stoljeća. Izd. Književnog kruga u Splitu, Biblioteka znanstvenih djela 76, Split, 1995., 415 str., 180-182 (prikaz).

(1995), br. 3

KOLAR-DIMITRIJEVIĆ, Mira. „Hrvatsko gospodarstvo u Nezavisnoj Državi Hrvatskoj”, 527-542.

(1996), br. 1-2

TURKALJ, Jasna. „Gospodarska problematika u listu Hervatska 1871. godine", 121-138.

(1998), br. 2

KOLAR-DIMITRIJEVIĆ, Mira. „Podružnica Hrvatskog Radiše u Gospiću 1920.-1921. godine”, 347-357.

STRČIĆ, Petar. „Tri knjige Jakova Sirotkovića o gospodarskoj osnovi propasti SFR Jugoslavije i velikosrpske agresije na Hrvatsku. Hrvatsko gospodarstvo 1945-1992. Ekonomski uzroci sloma Jugoslavije i oružane agresije na Hrvatsku, Zagreb, 1993.; Hrvatsko gospodarstvo. Privredna kretanja i ekonomska politika, Zagreb, 1996.; Memorandum SANU iz 1995. godine. (Kritički osvrt na knjigu K. Mihailovića i V. Krestića 'Memorandum SANU', odgovori na kritike), izdanje SANU, Beograd 1995. (IX), urednik M. Pantić, glavni tajnik SANU, str. 150, tisak GIP Kultura, Zagreb, 1996.", 406-411 (prikaz).

(1998), br. 3

KOLAR-DIMITRIJEVIĆ, Mira. „Belje između dva svjetska rata. Uloga politike u organizaciji beljskog gospodarstva od 1918. do 1941. godine”, 507525.

(1999), br. 2

KOLAR-DIMITRIJEVIĆ, Mira. „Projekt povijesti Zagrebačkog velesajma iz 1967. godine (u povodu 90-godišnjice Velesajma)", 319-339.

BRKLJAČA, Seka. „Bosanskohercegovački boksit kao strateška sirovina (1918.-1945.)", 341-357.

(1999), br. 3

ARTUKOVIĆ, Mato. „Srpska gospodarska, kulturna, prosvjetna i humanitarna društva”, 491-509.

MATANOVIĆ, Damir. „Zlata Živaković-Kerže, S tradicionalnih na nove puteve (Trgovina, obrt, industrija i bankarske ustanove grada Osijeka na prijelazu stoljeća od godine 1868. do 1918.), Hrvatski institut za povijest Zagreb, Podružnica za povijest Slavonije, Srijema i Baranje Slavonski Brod i Društvo za hrvatsku povjesnicu Osijek, Osijek 1999., 208 str., 659-660 (prikaz). 
(2000), br. 2

BIJELIĆ, Borislav. „Stjepan Sršan, Tvrtke u istočnoj Slavoniji: memorandumi od sredine 19. do sredine 20. stoljeća, Državni arhiv u Osijeku, Osijek, 1998., str. 160", 418-419 (prikaz).

(2001), br. 2

GOLEC, Ivica. „Obrtničko-radničko društvo ‘Banovac' u Petrinji (1885.1905.)", 453-474.

(2001), br. 3

VIRC, Zlatko. „Izvori za gospodarsku povijest na primjeru Brodske imovne općine u Vinkovcima”, 853-856.

PETRIĆ, Hrvoje. „Analiza regionalnih gospodarskih povijesnih radova na primjeru Podravine (Ludbreške, Koprivničke i Đurđevačke)”, 857-876.

ŠUTE, Ivica. „Gospodarska povijest u školskim udžbenicima od 1945. do 1999. godine", 877-882.

MATKOVIĆ, Hrvoje. „Jere Jareb, Državno gospodarstveno povjerenstvo Nezavisne Države Hrvatske od kolovoza 1941. do travnja 1945., Zagreb 2001. 799 str., 924-926 (prikaz).

(2002), br. 1

VRBANUS, Milan. „Promocija knjige akademika Vladimira Stipetića Povijest hrvatske ekonomske misli”, 286-287 (prikaz).

(2002), br. 3

VRBANUS, Milan. „Vladimir Stipetić, Povijest hrvatske ekonomske misli (1298.-1847.), Golden marketing, Zagreb 2001., 698 str.”, 998-1000 (prikaz).

(2004), br. 3

MIJATOVIĆ, Nikola. „Usklađivanje europskog PDV-a - povijesni prikaz”, 959-980.

BARIĆ, Nikica. „Nikola Žutić, Avio-industrija i vazduhoplovstvo u Kraljevini Jugoslaviji 1918-1945, Institut za savremenu istoriju, Beograd 2004., 214 str., 1228-1230 (prikaz).

(2005), br. 2

ARČABIĆ, Goran; KRALJEVIĆ, Iva. „Uloga listova 'Privreda Zagreba' i 'Zagrebačka panorama' u gospodarskom i društvenom životu Grada između 1954. i 1966. godine", 393-406.

VRBANUS, Milan. „Predstavljanje Biblioteke Hrvatska ekonomska misao", 561 (prikaz).

(2005), br. 3

VRBANUS, Milan. „Imbro Ignjatijević Tkalac, Hrvatsko gospodarstvo polovicom XIX. stoljeća, Zagreb 2004., 168 str., 822-824 (prikaz).

VOJAK, Danijel. „Ekonomska i ekohistorija: časopis za gospodarsku po- 
vijest i povijest okoliša. Zagreb-Samobor 2005., vol. I, br. 1., 208 str.”, 854-855 (prikaz).

(2007), br. 1

ANIĆ, Tomislav. „Normativni okvir podržavljenja imovine u Hrvatskoj/ Jugoslaviji 1944.-1946.", 25-62.

ŽIVAKOVIĆ-KERŽE, Zlata. „Podržavljenje imovine Židova u Osijeku u NDH", 97-116.

(2007), br. 2

JONJIĆ, Tomislav. „Sudbina švicarske imovine u Nezavisnoj Državi Hrvatskoj, 1941.-1945.", 385-418.

(2008), br. 3

ANIĆ, Tomislav. „Podržavljenje stranog kapitala u Hrvatskoj/Jugoslaviji 1945.-1946. na primjeru poduzeća Thonet Mundus d.d. u većinskom švicarskom vlasništvu", 819-832.

(2010), br. 2

GOTOVAC, Antonio. „Niall Ferguson, Uspon novca. Financijska povijest svijeta, Naklada Ljevak, Zagreb 2009., 374 str.”, 546-551 (prikaz).

(2010), br. 3

GRGIĆ, Stipica. „Ivica Šute, Slogom slobodi! Gospodarska sloga 1935.1941., Srednja Europa, Zagreb 2010., 475 str., $934-937$ (prikaz).

(2013), br. 1

CRNJAC, Maja. „Vladimir Ivanović, Geburtstag pišeš normalno. Jugoslavenski gastarbajteri u SR Nemačkoj i Austriji 1965.-1973., Institut za savremenu istoriju, Beograd, 2012., 400 str.", 173-179 (prikaz).

(2013), br. 2

MILJKOVIĆ, Marko. „Sajmovi automobila u Kraljevini Jugoslaviji kao mjesta promidžbe nacističke Njemačke”, 305-325.

BENCETIĆ, Lidija. „Marino Manin, Željka Pinjuh Ćorić, 150 godina zagrebačke plinare 1862.-2012., Gradska plinara Zagreb - Hrvatski institut za povijest, Zagreb, 2012., 184 str.", 378-379 (prikaz).

(2013), br. 3

BENCETIĆ, Lidija. „Iván T. Berend, Ekonomska povijest Europe dvadesetog stoljeća. Ekonomski režimi od laissez-fairea do globalizacije, Mate, Zagreb, 2011., 358 str.", 533-538 (prikaz).

(2014), br. 1

MELČIĆ, Dunja. „Ekonomsko-pravne devijacije i napreci iz sistemskog motrišta: Uz studiju Brune Schönfeldera, Vom Spätsozialismus zur Privatrechtsordnung. Eine Untersuchung über die Interdependenz zwischen Recht und Wirtschaft am Beispiel von Gläubigerschutz und Kredit, Berliner Wissenschaft s-Verlag, Berlin, 2012., 1108 str., 163-171 (prikaz). 
(2014), br. 2

DUKOVSKI, Vedran. „Problemi opskrbe i trgovine na području Zone B Julijske krajine u Istri 1945. - 1947. godine”, 277-294.

RATKAJEC, Hrvoje. „Prostorni vidici industrijalizacije u Istri od 1918. do 1940.: primjeri razvoja rudarske industrije i industrije građevnih materijala”, 319-339.

MATIJEVIĆ, Margareta. „Vera Katz, Društveni i ekonomski razvoj Bosne i Hercegovine 1945. - 1953., Institut za istoriju, Sarajevo, 2011., 432 str.”, 399401 (prikaz).

(2014), br. 3

STANIĆ, Igor. „Što pokazuje praksa? Presjek samoupravljanja u brodogradilištu Uljanik 1961-1968. godine”, 453-474.

(2015), br. 2

VRBANUS, Milan. „Ivica Golec, Razvoj novčanih zavoda na području današnje Sisačko-moslavačke županije 1860. - 1945. (Sisak: Državni arhiv, 2014), 303 str.", 429-431 (prikaz).

(2018), br. 1

JOVANOVIĆ, Vladan. „Jugoslavensko-američka opijumska suradnja 1929. - 1941. godine”, 35-64.

BARIĆ, Nikica. „Ulrike Schult, Zwischen Stechuhr und Selbstverwaltung: Eine Mikrogeschichte sozialer Konflikte in der jugoslawischen Fahrzeugindustrie 1965-1985, Studien zur Geschichte, Kultur und Gesellschaft Südosteuropas, Band 15 (Berlin: Lit Verlag, 2017), 358 str.", 193-195 (prikaz).

(2018), br. 2

MASLEK, Jasenka. „Razvoj zadrugarstva na poluotoku Pelješcu u prvoj polovini XX. stoljeća”, 391-420.

\section{Literatura}

BIĆANIĆ, Rudolf. „Ekonomska povijest medju ekonomskim i historijskim naukama”. Zgodovinski časopis (Kosov zbornik) 6-7 (1952-1953): 820-826.

BIĆANIĆ, Rudolf. „Još jedna riječ o ekonomskoj povijesti”. Zgodovinski časopis 9 (1955): 197-199.

BOLDIZZONI, Francesco. The Poverty of Clio: Resurrecting Economic History. Princeton: Princeton University Press, 2011.

BRANĐOLICA, Tomislav. „Poduzetnička historija i hrvatska historiografija nakon 1945." Pro tempore 8-9 (2010-2011): 60-70.

DRAGIČEVIĆ, Adolf. Leksikon političke ekonomije. Zagreb: Informator, ${ }^{2} 1983$.

ERCEG, Ivan, ur. Bibliographia historico-oeconomica Iugoslaviae. Zagreb: Izdavački zavod Jugoslavenske akademije znanosti i umjetnosti, 1978. 
FIELD, Alexander J. „Economic history”. U: The New Palgrave Dictionary of economics (second edition), vol. 2, ur. Steven N. Durlauf i Lawrence E. Blume. New York: Palgrave Macmillan, 2008, 694-697.

GROSS, Mirjana. „Historija i društvene znanosti”. Časopis za suvremenu povijest 7 (1975), br. 2: 71-99.

GROSS, Mirjana. Suvremena historiografija. Korijeni, postignuća, traganja. Zagreb: Novi Liber; Zavod za hrvatsku povijest Filozofskog fakulteta Sveučilišta u Zagrebu, 2001.

JELASKA MARIJAN, Zdravka. „Pedeset godina Časopisa za suvremenu povijest: bibliometrijska analiza (1969. - 2018.)". Časopis za suvremenu povijest 51 (2019), br. 1: 59-94.

KOLAR-DIMITRIJEVIĆ, Mira. „Gospodarska povijest”. Časopis za suvremenu povijest 33 (2001), br. 3: 839.

KOLAR-DIMITRIJEVIĆ, Mira. „Miroslava Despot, prva ekonomska povjesničarka Hrvatske”. Ekonomska i ekohistorija 12 (2016), br. 1: 136-150.

KOLAR-DIMITRIJEVIĆ, Mira. „O radu njemačkoga društva za povijest poduzeća”. Acta historico-oeconomica lugoslaviae 17 (1990): 227-230.

KOLAR-DIMITRIJEVIĆ, Mira. „Projekt povijesti Zagrebačkog velesajma iz 1967. godine. (U povodu 90-godišnjice Velesajma)". Časopis za suvremenu povijest 31 (1999), br. 2: 319-339.

KOLAR-DIMITRIJEVIĆ, Mira; PETRIĆ, Hrvoje. „Nekoliko uvodnih riječi. Novi časopis: Ekonomska i ekohistorija”. Ekonomska i ekohistorija 1 (2005), br. 1: 5-7.

KORUNIĆ, Petar. „Prof. dr. Mira Kolar - život i djelo”. U: Zbornik Mire Kolar-Dimitrijević: zbornik radova povodom 70. rođendana, ur. Damir Agičić. Zagreb: Filozofski fakultet Sveučilišta u Zagrebu, Odsjek za povijest, 2003, 7-16.

NOVAK, Grgo. Split u svjetskom prometu. Split: Naklada knjižare Vinko Jurić, 1923.

PAVIĆ, Hrvoje. „Ekonomska povijest - prikaz ekonomske djelatnosti Ivana Kapistrana I. pl. Adamovicha de Csepin”. Diplomski rad, Sveučilište Josipa Jurja Strossmayera u Osijeku, 2015.

PAVLIČEVIĆ, Dragutin. „Uz osamdesetu obljetnicu života dr. Miroslave Despot”. Radovi Zavoda za hrvatsku povijest Filozofskoga fakulteta Sveučilišta u Zagrebu 25 (1992), br. 1: 307-309.

PEKLIĆ, Ivan. „Bibliografija radova iz gospodarske povijesti i ekohistorije objavljenih u Časopisu za suvremenu povijest i Crisu - časopisu Povijesnog društva Križevci”. Ekonomska i ekohistorija 3 (2007), br. 1: 206-210.

PETRIĆ, Hrvoje. „Prilozi poznavanju historiografije o gospodarskoj povijesti u Hrvatskoj”. U: Vizija raziskav slovenske gospodarske in družbene zgodovine, ur. Darja Mihelič. Ljubljana: Zgodovinski inštitut Milka Kosa; ZRC SAZU, 2014, 97-124. 
RAUKAR, Tomislav. Srednjovjekovne ekonomije i hrvatska društva. Zagreb: Filozofski fakultet, Odsjek za povijest, 2003.

ROKSANDIĆ, Drago. „Na kraju prvog broja: Čemu “Eko-Eko'?” Ekonomska i ekohistorija 1 (2005), br. 1: 147-149.

STIPETIĆ, Vladimir. Dva stoljeća razvoja hrvatskoga gospodarstva (1820.2005.). Zagreb: Hrvatska akademija znanosti i umjetnosti, 2012.

SUNAJKO, Goran, ur. Ekonomski leksikon. Zagreb: Leksikografski zavod „Miroslav Krleža”; Masmedia, ${ }^{2} 2011$.

VUČO, Nikola. „Industrijska revolucija u jugoslavenskim zemljama (Teze za diskusiju)". Acta historico-oeconomica 1 (1974), br. 1: 9-15.

ZWITTER, Fran. „Odgovor”. Zgodovinski časopis 9 (1955): 199-201.

ŽIVAKOVIĆ-KERŽE, Zlata. „Doprinos Ive Mažurana istraživanju gospodarske povijesti Slavonije, Srijema i Baranje”. Književna revija: časopis za književnost i kulturu 54 (2014), br. 3-4: 99-107.

ŽIVAKOVIĆ-KERŽE, Zlata. „Zastupljenost tema gospodarske povijesti Slavonije, Srijema i Baranje u hrvatskoj historiografiji (S primjerima i o odnosu prema temama iz historijske demografije)". U: Zbornik Mire Kolar-Dimitrijević: zbornik radova povodom 70. rođendana, ur. Damir Agičić. Zagreb: Filozofski fakultet Sveučilišta u Zagrebu, Odsjek za povijest, 2003, 497-508. 


\section{SUMMARY}

\section{Economic History in the Journal of Contemporary History (1969-2018)}

This paper offers an overview of the approaches to economic history in the Journal of Contemporary History. First, the possible definitions of the term 'economic history' are presented, along with a brief overview of the development of that scientific subdiscipline in Croatian and international historiography. The main part of the paper is devoted to an overview of the contents of relevant works printed in the Journal, which is followed by a description and analysis of the numeric indicators of articles, topics covered, categories, and authors of papers and other contributions published in the Journal from its launch in 1969 to the end of 2018. In addition to several tables and graphics, the author has compiled a full biography of 51 articles and 32 reviews related to economic history, which has been attached to the article as an appendix. The Journal of Contemporary History reflects a relatively poor presence of works dealing with economic history in Croatian historiography, but shows a different trend when its internal production is examined. The 1990s, which are usually regarded as a time when research in economic history within the frame of Croatian historiography waned, were also the decade when a greater number of works on economic history were published in the Journal than in any previous decade. This overview also points to the often highlighted problem of the lack of systematic support, i.e. the lack of institutional infrastructure and programmes aimed at supporting the development of economic history as well as the lack of team- and interdisciplinary work. Scientific production in this field depends on the enthusiasm of individuals, who are few in number. The most prominent author in this context is Mira Kolar Dimitrijević, who has written one-third of all economic history articles published in the Journal of Contemporary History.

Key words: Journal of Contemporary History; economic history; historiography 